JLARC 3 (2009) 1-20

\title{
FROM HOMOOUSION TO HOMOHYPOSTATON: PATRIARCH METHODIUS OF CONSTANTINOPLE AND POST-PATRISTIC TRINITARIAN THEOLOGY
}

\author{
Dirk Krausmüller, Cardiff University (dkrausmuller@hotmail.com)
}

\begin{abstract}
This article attempts to demonstrate that the ninth-century patriarch Methodius of Constantinople undertook a radical deconstruction of the conceptual framework of traditional Trinitarian theology, which resulted in the subversion of all recognisable differences between the second and the third person of the Trinity. It consists of three parts: a detailed analysis of a Trinitarian excursus in Methodius' Life of the Iconophile confessor Euthymius of Sardes, which pays close attention to terminological and syntactical ambiguities; a comparison of this excursus with similar discussions by other authors of the time; and the identification of developments in the Late Antique theological discourse that can explain Methodius' particular understanding of the Trinity.
\end{abstract}

Following decades of bitter controversy the Second Ecumenical Council declared in 381 that the Christian God was three persons sharing one common divinity. This formula proved to be a lasting success and eventually came to be recognised by all Christian communities. By contrast, the conceptual framework that explained and justified it fared much less well: based on a highly complex and idiosyncratic combination of disparate philosophical notions, it caused great difficulties to later theologians who struggled to make sense of it. ${ }^{1}$

In the sixth century this obscurity resulted in a new controversy when theologians such as John Philoponus proposed a 'Tritheistic' interpretation of the Trinity and the defenders of the traditional view either fell into the 'Sabellian' trap or tried to

\footnotetext{
${ }^{1}$ Contemporary scholarship has proposed several conflicting interpretations. Cf. the most recent interpretation by J. Zachhuber, Human Nature in Gregory of Nyssa. Philosophical Background and Theological Significance (Supplements to Vigiliae Christianae, 46; Leiden, Boston, Cologne, 2000), pp. 17-122.

Dirk Krausmüller, 'From Homoousion to Homohypostaton: Patriarch Methodius of Constantinople and Post-Patristic Trinitarian Theology,' in: Journal for Late Antique Religion and Culture 3 (2009) 1-20; ISSN: 1754-517X; Website: http://www.cardiff.ac.uk/clarc/jlarc
} 
solve the problem by mere fiat. ${ }^{2}$ Tritheism was finally overcome both in the Monophysite and in the Chalcedonian churches (although with questionable success), but this does not mean that Trinitarian speculation came to an end. In a previous publication I have argued that it was alive and well in the seventh century when Leontius of Jerusalem proposed a radical reinterpretation of the inner-Trinitarian relations through substitution of the conventional essentialist and static framework with a new voluntaristic and developmental one. ${ }^{3}$ In this article I will attempt to show that the discussion continued into the eighth and ninth centuries. These centuries are even less well studied than the immediately preceding period and there has been a tendency to focus on creedal statements and to assume that these statements express the views of the authors who quoted them. ${ }^{4}$ It goes without saying that this approach is methodologically unsound. Creedal formulae are shibboleths of orthodoxy and can therefore not be taken as evidence that their content was truly accepted or even understood. For a proper evaluation of an author's views on the Trinity we must instead look at passages where he presents his views in the form of an argument and we must analyse his statements as carefully as those of authors of the fourth and fifth centuries instead of being satisfied with superficial readings.

In what follows I will focus on Methodius of Syracuse, a monk and patriarchal deacon in Constantinople who rose to prominence as one of the leaders of the resistance against official Iconoclasm in the early ninth century and who as patriarch was later responsible for the restoration of the cult of images in the Orthodox Church. ${ }^{5}$ Methodius was not only a church politician but also a prolific author of saints' lives and religious poems. I have written elsewhere about his anthropological speculations, arguing that they are highly original reinterpretations of Patristic concepts with the aim of making these concepts relevant in the radically changed world of the Early Middle Ages. ${ }^{6}$ Now I hope to show that his views on the Trinity are no less original and that he embarks on a radical deconstruction of the conceptual framework of traditional Trinitarian theology, which results in the subversion of all recognisable differences between the second and the third person of the Trinity. In order to make my case I will analyse a passage in a Trinitarian excursus in Methodius' Life of the Iconophile confessor Euthymius of Sardes, establish the function of this passage within its context, compare Methodius' treatment of the

${ }^{2}$ For a brief overview of the controversy cf. R. Y. Ebied, A. van Roey, L. R. Wickham, Peter of Callinicum. Anti-Tritheist Dossier (OLA 10; Leuven, 1981), pp. 20-33.

3 D. Krausmüller, 'Divine self-invention: Leontius of Jerusalem's reinterpretation of the Patristic model of the Christian God', The Journal of Theological Studies. New Series 57 (2006), pp. 526-45.

${ }^{4}$ Cf. e.g. H.-G. Beck, Kirche und theologische Literatur im byzantinischen Reich (Handbuch der Altertumswissenschaft, 12.2.1 ; Munich, 1959), p. 308, on John of Damascus.

${ }^{5}$ For Methodius' biography and writings, cf. R.-J. Lilie, C. Ludwig, Th. Pratsch, I. Rochow, F. Winkelmann, Prosopographie der mittelbyzantinischen Zeit, I.3: Leon - Placentius (Berlin and New York, 2000), pp. 233-239, no. 4977, with literature.

6 Cf. D. Krausmüller, 'Divine sex: Patriarch Methodios's concept of virginity', in L. James (ed.), Desire and Denial in Byzantium (Aldershot, 1999), pp. 57-65; D. Krausmüller, 'Exegeting the Passio of St Agatha: Patriarch Methodius ( $\dagger$ 847) on sexual differentiation and the perfect "man"', Byzantine and Modern Greek Studies 33 (2009) 1-16.

Dirk Krausmüller, 'From Homoousion to Homohypostaton: Patriarch Methodius of Constantinople and Post-Patristic Trinitarian Theology,' in: Journal for Late Antique Religion and Culture 3 (2009) 1-20; ISSN: 1754-517X; Website: http://www.cardiff.ac.uk/clarc/jlarc 
topic with similar discussions by other authors of the time, and identify developments in the Late Antique theological discourse that can explain his particular understanding of the Trinity.

I have chosen to start with the in-depth analysis of just a few lines of text because Methodius is an extremely demanding author. His intentions reveal themselves only to the attentive reader who is prepared to fill the gaps in his often incomplete statements. ${ }^{7}$ This task is not made any easier by the way in which Methodius presents his argument. It could be said that he was the Heidegger of his time: he coins new words or uses existing words in unexpected ways and he deliberately creates ambiguity at the syntactical and lexicographical levels. ${ }^{8}$ In what follows I have attempted to make my case without involving these features so as not to encumber the discussion with long digressions, but it has not always been possible to exclude them altogether.

I.

The passage in the Life of Euthymius of Sardes that I have chosen as my starting point is part of an excursus about the divine image in man, which is presented in the form of an exegesis of Genesis 1:26. ${ }^{9}$ Methodius starts from the traditional view that the divine image in man is to be identified with his $\lambda$ orixóv but then adds that the formula $x \alpha \tau$ ' cixóv $\alpha$ in Genesis 1:26 must not be understood as referring solely to the Word as the second person of the Trinity. ${ }^{10}$ This rejection of a well-established interpretation of the verse is based on the following considerations. Firstly there is the grammatical argument that the pronoun $\dot{\eta} \mu \varepsilon \tau^{\prime} \varrho \alpha \nu$ and the verb $\pi 0 \imath \eta^{\prime} \sigma \omega \mu \varepsilon v$ do not refer to two persons but at least to three, ${ }^{11}$ and secondly Methodius reasons that if man were merely $\lambda o \gamma$ ixós he would only be the image of the second person of the Trinity, which cannot exist on its own, and supports this contention with the observation that in man, too, the $\lambda$ ó $\gamma \circ \varsigma$ cannot function without the 'mind' (voṽs)

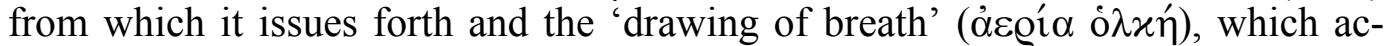
companies it. ${ }^{12}$ With this comparison Methodius introduces the concept of the Imago Trinitatis, which sees Father, Son and Spirit and their relations with each other reflected in the human mind, word and breath. ${ }^{13}$

\footnotetext{
${ }^{7}$ Cf. D. Krausmüller, 'Being, seeming and becoming: Patriarch Methodius on divine impersonation of angels and souls and the Origenist alternative', forthcoming in Byzantion.

8 D. Krausmüller, 'Strategies of equivocation and the construction of multiple meanings in Middle Byzantine texts', Jahrbuch der Österreichischen Byzantinistik 56 (2006), pp. 1-11.

9 Methodius, Life of Euthymius, 32-35, ed. and trans. J. Gouillard, 'La vie d'Euthyme de Sardes (+ 831), un œuvre du patriarche Méthode', Travaux et Mémoires 10 (1987), pp. 1-101, esp. pp. 6773.651-752.

10 Cf. e.g. Anastasius of Sinai, Sermo II.1, ed. K.-H. Uthemann, Anastasii Sinaitae sermones duo in constitutionem hominis secundum imaginem Dei necnon opuscula adversus monotheletas (CC. SG, 12; Turnhout and Leuven, 1985), p. 39, 11. 63-68.

11 Methodius, Life of Euthymius, 33, ed. Gouillard, p. 69, 11. 681-85.

12 Methodius, Life of Euthymius, 33, ed. Gouillard, p. 69, 11. 686-91.

13 Cf. L. Thunberg, Microcosm and mediator: the theological anthropology of Maximus the Confessor (Acta Seminarii Neotestamentici Upsaliensis, 25; Lund, 1965), pp. 137-39.

Dirk Krausmüller, 'From Homoousion to Homohypostaton: Patriarch Methodius of Constantinople and Post-Patristic Trinitarian Theology,' in: Journal for Late Antique Religion and Culture 3 (2009) 1-20; ISSN: 1754-517X; Website: http://www.cardiff.ac.uk/clarc/jlarc
} 
This concept, which had already been employed by Gregory of Nazianzus, ${ }^{14}$ was very popular in the late Patristic discourse and is regularly found in authors such as Anastasius of Antioch, Maximus the Confessor, Anastasius of Sinai and John of Damascus. ${ }^{15}$ In Methodius' case its adaptation results in a shift in the meaning

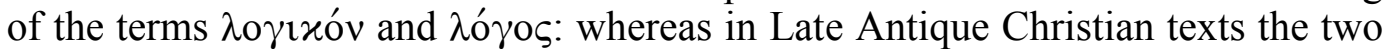
words had denoted 'rationality' and 'reason', Methodius understands $\lambda$ o $\gamma$ ixóv in its etymological sense as 'wordliness', 16 and he identifies the human $\lambda$ ó $\gamma \circ \varsigma$ with

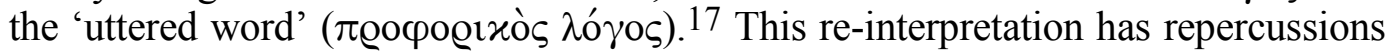
for the divine archetype: by linking the distinctions between the three divine persons to articulated speech and by discussing them in the context of creation Methodius gives the impression that these distinctions are bound up with the divine operations ad extra, which implies a modalist understanding of the Trinity.

While being of questionable orthodoxy, such a position would still be well within the parameters of the Late Antique Christian discourse. However, detailed analysis of one sentence within the excursus shows that this is not Methodius' last word on the topic and that he aims at subverting the very framework on which traditional Trinitarian theology is based:

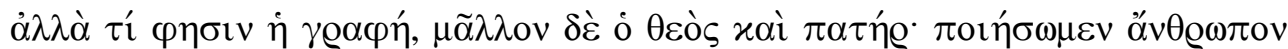

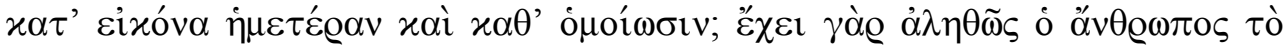

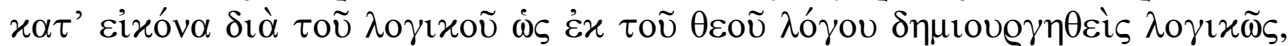

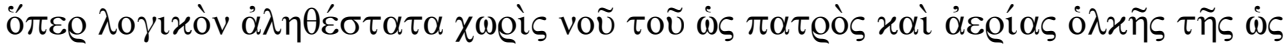

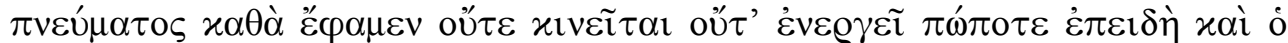

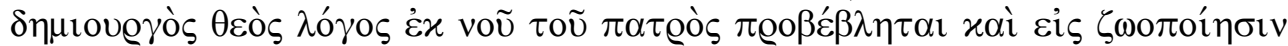

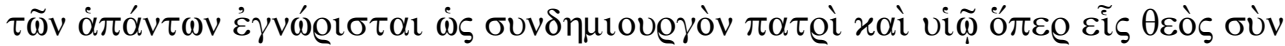

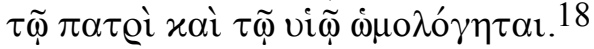

14 Gregory of Nazianzus, Oratio XXIII.11, ed. and trans. J. Mossay, Grégoire de Nazianze,

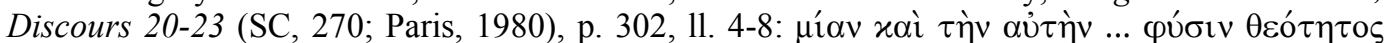

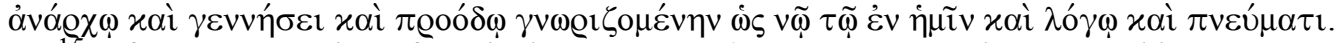

15 Cf. e.g. Anastasius of Antioch, Expositio dogmatica I.31, ed. S. N. Sakkos, Anastasii I

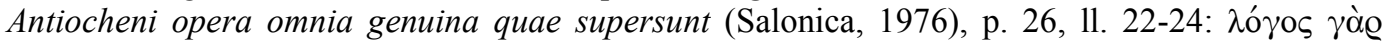

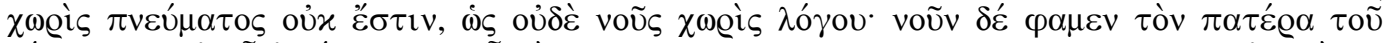

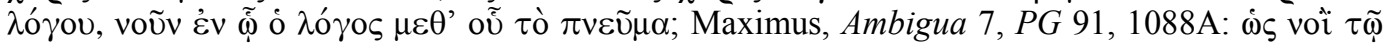

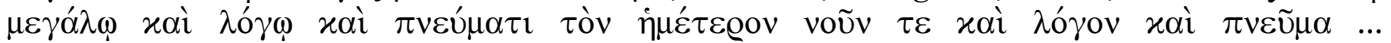
$\pi \varrho 0 \sigma \chi \omega \mathrm{\eta} \sigma \alpha \nu \tau \varepsilon \zeta ;$ John of Damascus, De duabus in Christo voluntatibus, 30, ed. B. Kotter, Johannes von Damaskos, Schriften, IV: Opera polemica, Liber de haeresibus (PTS, 22; Berlin,

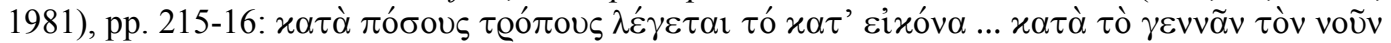

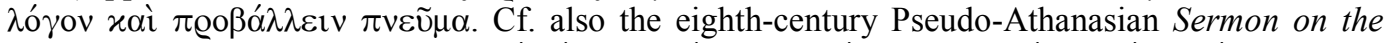

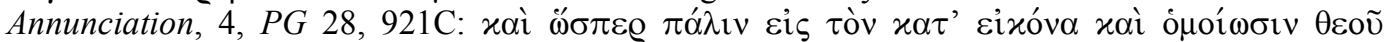

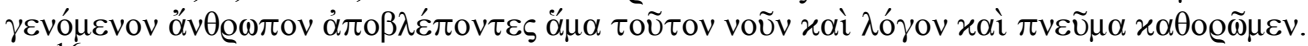

16 Gouillard translates $\lambda$ o $\gamma$ ixóv as 'la faculté de verbe', but states in footnote 135 on page 70: 'On aimerait traduire par "verbéité".'

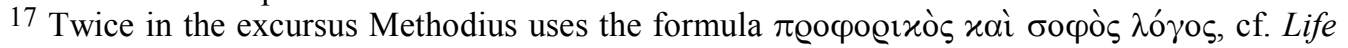
of Euthymius, 33, ed. Gouillard, pp. 69-71, 11. 707-8, The notion of 'wisdom' is usually closely related to rationality but since it is combined with 'articulate' it is more likely to refer to Proverbs

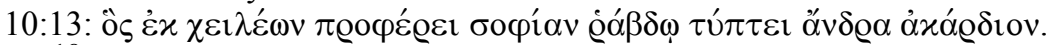

18 Methodius, Life of Euthymius, 33, ed. Gouillard, p. 69, 11. 692-98.

Dirk Krausmüller, 'From Homoousion to Homohypostaton: Patriarch Methodius of Constantinople and Post-Patristic Trinitarian Theology,' in: Journal for Late Antique Religion and Culture 3 (2009) 1-20; ISSN: 1754-517X; Website: http://www.cardiff.ac.uk/clarc/jlarc 
But why does Scripture or rather the God and Father say: 'Let us make man according to our image and according to our likeness'? For man has indeed the (sc. status of being) according to the image through his 'wordliness' as having been created by the God Word in a 'wordly' manner, which 'wordliness', as we have said, neither moves nor operates at any time without the mind as father and the drawing of breath as spirit, since the creator God Word, too, is projected from the mind, that is, the Father, and recognised is for the vivification of all things as being co-creator with the Father and the Son that which is confessed as one God with the Father and the Son. 19

This sentence consists of two parts, a main clause and a subordinate clause introduced by the conjunction $\varepsilon \pi \varepsilon i \delta \eta$. The main clause merely sums up the results of the previous discussion. By contrast, the subordinate clause introduces an aspect that Methodius had not yet set out in detail, namely the inner-Trinitarian relations that provide the starting point for the divine image in man. At this point one would expect a straightforward exposé of Trinitarian theology. However, this is not what Methodius presents us with. When one reads the sentence for the first time one immediately recognises several oddities. The subordinate clause starts as a statement about the Word and then switches to the Spirit but in such a way that this

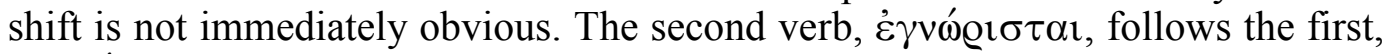

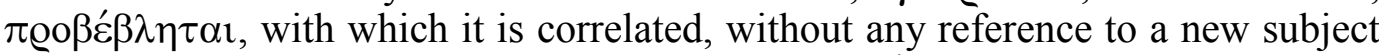
and a reader will assume that it still refers back to $\lambda$ ó $\gamma \circ \varsigma$, in particular since both verbs are used in the third person singular of the perfect passive. That we are dealing

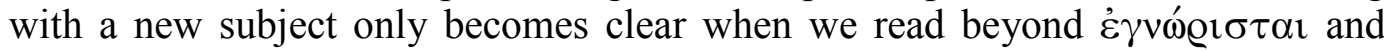
even then this subject is not named but can only be inferred by a process of exclusion: once we come across the Dative vi $\tilde{\omega}$ we know that we are dealing with a third entity beside the Father and the Son, which our knowledge of the Christian creed then causes us to identify with the Holy Spirit. There can be no doubt that this ambiguity is created deliberately: nothing would have been easier than to insert a subject $\tau$ ò $\alpha$ zrov $\pi v \varepsilon \tilde{v} \mu \alpha$ either immediately before or immediately after

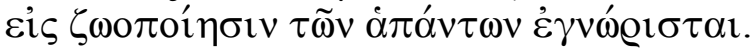

Indeed, further analysis reveals that Methodius creates ambiguity not only through misleading syntax but also through the use of equivocal individual expressions. The

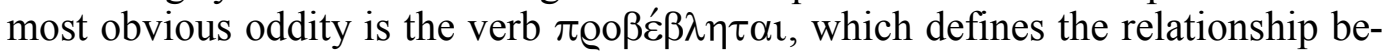
tween the Father and the Word through comparison with the relationship between

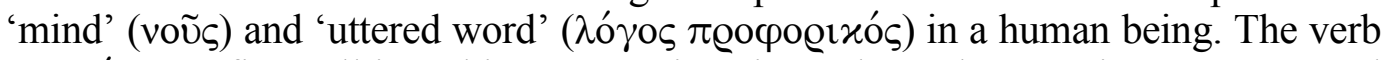
$\pi \mathrm{Q} \beta \alpha \alpha^{\prime} \lambda \lambda \varepsilon \iota v$ fits well into this context since it can have the meaning 'to utter' and

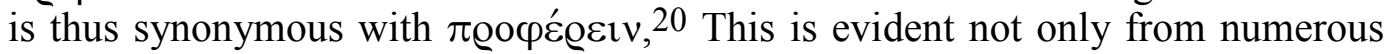

19 Cf. Gouillard's translation: 'Puisque Dieu le Verbe créateur lui-meme a été émis par l'intellect Père et puisqu'a été révélé pour la vivification de l'univers, en tant que co-créateur avec le Père et le Fils, Celui qui a été confessé comme un seul et même Dieu avec le Père et le Fils.'

${ }^{20}$ According to the Lexicon of Liddell \& Scott this use is first attested in the imperal period, cf. e.g. Diodorus Siculus, Bibliotheca historica, III.8.3, ed. F. Vogel (Leipzig, 1888), vol. I, p. 276,

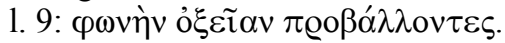

Dirk Krausmüller, 'From Homoousion to Homohypostaton: Patriarch Methodius of Constantinople and Post-Patristic Trinitarian Theology,' in: Journal for Late Antique Religion and Culture 3 (2009) 1-20; ISSN: 1754-517X; Website: http://www.cardiff.ac.uk/clarc/jlarc 
Late Antique and Byzantine theological texts, ${ }^{21}$ but also from Methodius' Encomium

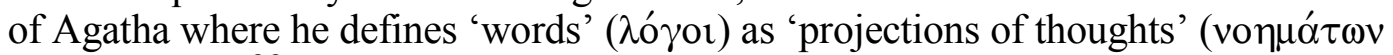
$\pi \varrho \circ \beta \lambda \eta \mu \alpha \tau \alpha) .{ }^{22}$ When we look at the context of the sentence under discussion we find that 'projection' is not the only way in which this relationship is conceptualised

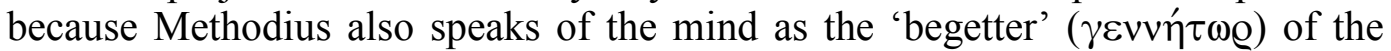
word. ${ }^{23}$ Such mixing of metaphors was common enough at the time: Photius, for example, once castigates the Monophysites as 'begetters of outlandish ... projections'

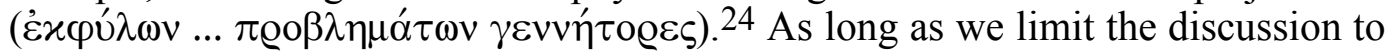
the human sphere Methodius' statement thus seems to be entirely appropriate. However, it must be remembered that $\pi \varrho \circ \beta \varepsilon^{\prime} \beta \lambda \eta \tau \alpha \iota$ appears in a specifically Trinitarian context where it denotes the relation between the Father and the Son. Early Christian authors such as Justin or Eusebius used $\gamma \varepsilon v v \tilde{\alpha} \nu$ and $\pi \varrho \circ \beta \alpha ́ \lambda \lambda \varepsilon i v$ interchangeably in their discussions of the relationship between Father and Son, evidently prompted by the Johannine appellation 'Word' for the Son. ${ }^{25}$ This unselfconscious use of the two terms, however, came to an end in the later fourth century when the status of the Spirit became an issue. From then on the verb $\pi \varrho \circ \beta \alpha$ ó $\lambda \lambda \varepsilon i v$ denotes exclusively the procession of the Spirit from the Father whereas the relationship between Father and Son is unequivocally expressed through $\gamma \varepsilon v v \tilde{\alpha} v$. Gregory of Nazianzus, for example, states that there is 'the Father and the Son and the Holy Spirit: the one being generator and projector ... and the others either product of generation or product of projection' (o $\pi \alpha \tau \grave{\eta} \varrho x \alpha i$

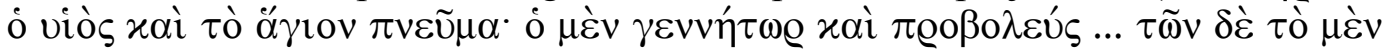

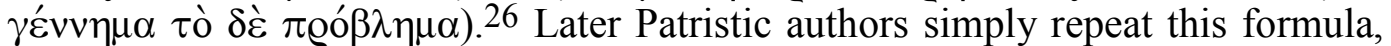
which by then had become fossilised, 27 both in creedal statements and also in the particular context of the Imago Trinitatis. ${ }^{28}$ This remarkable terminological consistency is, of course, not accidental: it is demanded by orthodox Trinitarian theology. The Cappadocians had conceptualised the Trinity as one substance in three

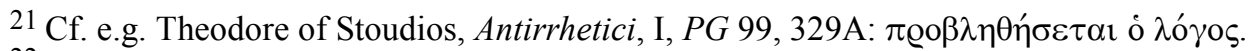

22 Methodius, Encomium of Agatha, 16, ed. E. Mioni, 'L'encomio di S. Agata di Metodio patriarcha di Costantinopoli', ABoll 68 (1950) p. 58-93, esp. p. 84, 1. 29.

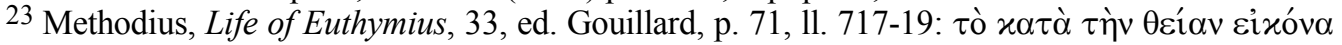

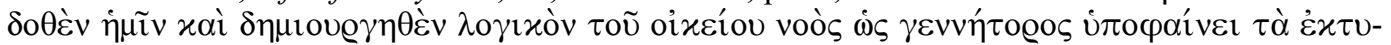
$\pi \hat{\omega} \mu \alpha \tau \alpha$.

24 Photius, Letters, 285, ed. B. Laourdas and L. G. Westerink, Photii Patriarchae Constantinopolitani Epistulae et Amphilochia, vol. 3: Epistularum pars tertia (Leipzig, 1985), p. 102, 11. 122-23.

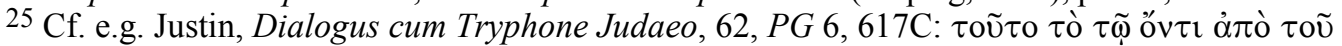

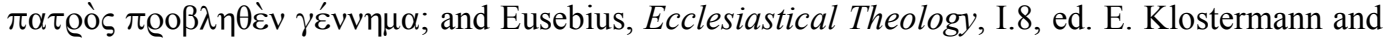
G. C. Hansen, Eusebius, Werke, IV: Gegen Marcell, Uber die kirchliche Theologie, Die Frag-

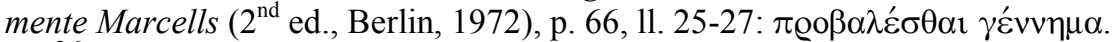

26 Gregory of Nazianzus, Oratio, XXIX.9, ed. P. Gallay, Grégoire de Nazianze, Discours $27-$ 31 (Discours théologiques) (SC, 250; Paris, 1978), p. 180, 11. 14-17.

27 Of course, $\pi \varrho \circ \beta \alpha ́ \lambda \lambda \varepsilon \sigma \theta \alpha \mathrm{l}$ is not always used in such contexts. Many theologians preferred

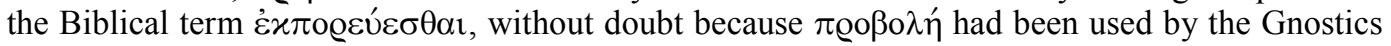
as a technical term for 'emanation', cf. Irenaeus, Adversus Haereses I.2.6, PG 67, 465A.

28 Cf. e.g. John of Damascus, De duabus in Christo voluntatibus, 30, ed. Kotter, Schriften, IV,

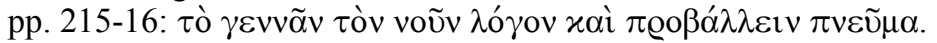

Dirk Krausmüller, 'From Homoousion to Homohypostaton: Patriarch Methodius of Constantinople and Post-Patristic Trinitarian Theology,' in: Journal for Late Antique Religion and Culture 3 (2009) 1-20; ISSN: 1754-517X; Website: http://www.cardiff.ac.uk/clarc/jlarc 
hypostases and had defined hypostasis as 'substance with idioms' (oủoí $\alpha \mu \varepsilon \tau \grave{\alpha}$

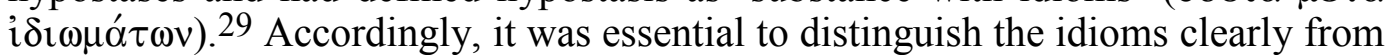
each other and to avoid terminological ambiguities. Patristic theologians therefore took pains to emphasise the difference between the second and the third person of the Trinity even when Scripture appears to use the same terms to express their relation with the first person. The sixth-century author Anastasius of Antioch, for example, states in his first Dogmatic Exposition:

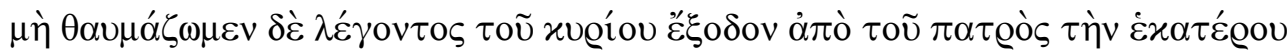

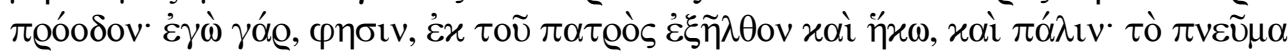

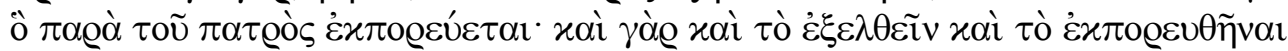

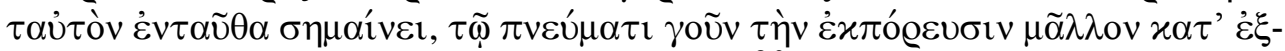

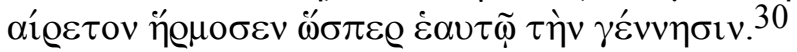

Let us not wonder that the Lord called 'exit' the coming forth of either person from the Father, for he says: 'I have come out of the father and am come', and again: 'the Spirit, which comes from the Father'. Here 'coming out' and 'having come out' mean the same thing. Yet he rather attributed 'coming out' specifically to the Spirit, just as 'birth' to himself.

It is evident that Methodius takes exactly the opposite approach when he gives the Son a characteristic that had for hundreds of years been reserved for the Spirit but it is not yet clear why he should have done so. One possible explanation would be to assume a lapsus calami in particular since Methodius was, of course, aware of the 'correct' version: in the Life of Euthymius he speaks of the 'inconfoundibility of the persons' ( $\tau$ ò $\alpha \sigma u ́ \gamma \chi \cup \tau o v ~ \tau \tilde{\omega} v \pi \varrho \circ \sigma \omega ́ \pi \omega v$ ), ${ }^{31}$ and in his Passio of Denys he lets the saint profess his faith in 'a Father ... the ingenerate, a Son, alone generate

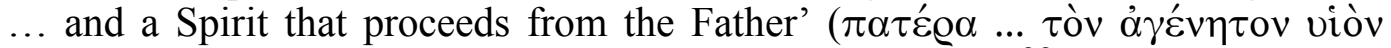

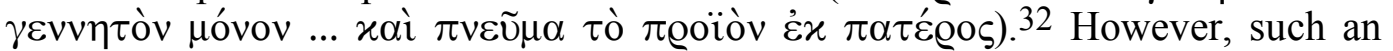
explanation cannot account for the deliberately ambiguous syntax and it is also gainsaid by further equivocation at the level of individual expressions. ${ }^{33}$

${ }^{29}$ For later references cf. Thalassius the Libyan, Centuriae, IV.88, PG 91, 1468B: vं ó $\sigma \tau \alpha \sigma ı$

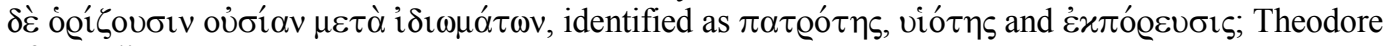
of Stoudios, Antirretici, I.1, PG 99, 329B.

30 Anastasius of Antioch, Expositio dogmatica, I.1.27, ed. Sakkos, p. 25, 11. 3-8.

${ }^{31}$ Methodius, Life of Euthymius of Sardes, 33, ed. Gouillard, p. 69, 11. 674-75.

32 Methodius, Encomium of Denys, 10, ed. J. C. Westerbrink, Passio S. Dionysii Areopagitae Rustici et Eleutherii uitgegeven naar het Leidse Handschrift Vulcanianus 52 (Alphen, 1937), p. 54, 11. 21-25.

33 Further study may well reveal that Methodius' views are not as idiosyncratic as they might first seem. The eleventh-century theologian and spiritual author Nicetas Stethatos deals in his writings extensively with the Imago Trinitatis and expresses ideas that are strikingly similar to what we have found in Methodius. Nicetas' treatise De anima, for example, contains in chapter 24 a passage where the soul is characterised as 'having a mind as its purest part, father and projector

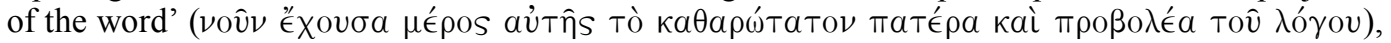
ed. J. Darrouzès, Nicétas Stéthatos, Opuscules et lettres (Sources Chrétiennes, 81, Paris, 1961), p. 86, 11. 6-7. This statement contains two oddities: firstly, there is no reference to the Spirit, and secondly the term $\pi \rho \circ \beta \circ \lambda \epsilon u ́ s$, which traditionally defined the relationship between the first and

Dirk Krausmüller, 'From Homoousion to Homohypostaton: Patriarch Methodius of Constantinople and Post-Patristic Trinitarian Theology,' in: Journal for Late Antique Religion and Culture 3 (2009) 1-20; ISSN: 1754-517X; Website: http://www.cardiff.ac.uk/clarc/jlarc 


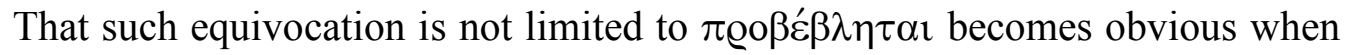
we turn to the part of the sentence that seems to refer to the Holy Spirit. After $\pi \mathrm{Q}$ -

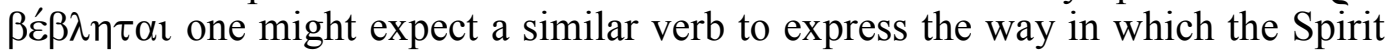
is related to the Father, as is indeed often found in Patristic texts in statements such

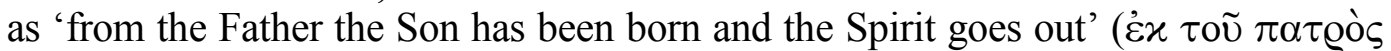

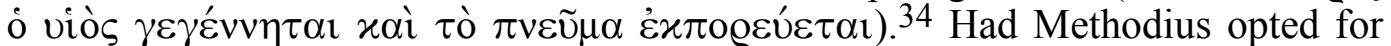
such a straightforward statement the implications of an attribution of $\pi \varrho \circ \beta 0 \lambda \dot{\eta}$ to the Word would immediately have become evident to his readers. Instead, he chooses to employ the verb $\gamma v \omega \varrho i \zeta \varepsilon i v$, which while being correlated with $\pi \mathrm{QO}-$ $\beta \varepsilon^{\prime} \beta \lambda \eta \tau \alpha l$ and also appearing in the perfect passive, does not denote an innerTrinitarian relation. However, this does not mean that there is no connection be-

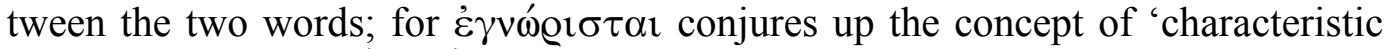

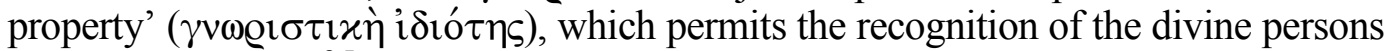
as distinct entities. 35 Since the second part of the sentence seems to identify the

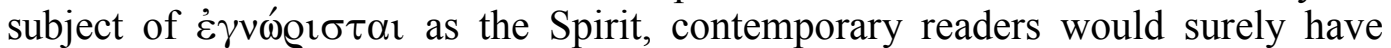
been reminded that one of the terms to denote this 'mark' $(\gamma \nu \omega ́ \varrho ı \sigma \mu \alpha)$ in the case of the Spirit is 'projection' ( $\pi \varrho \circ \beta \circ \lambda \eta$, $\pi \varrho \circ \beta \alpha$ $\alpha \lambda \varepsilon \sigma \theta \alpha \imath$ ), which as we have seen has just been applied to the Word. Therefore one can argue that Methodius chose this verb in order to indicate in a rather more oblique way that he deviated from the earlier Patristic consensus with its insistence that the characteristic idioms of each person are not communicable or interchangeable. 36

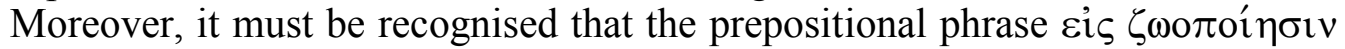
$\tau \tilde{\omega} v \dot{\alpha} \pi \alpha ́ v \tau \omega v$ is ambiguous. While in many texts the Holy Spirit is called 'life-

the third persons of the Trinity, is used alongside $\pi a \tau \eta \dot{\rho} \rho$ to characterise the relationship between the first and second persons of the Trinity.

34 Pseudo-Athanasius, Dialogi duo contra Macedonianos, PG 28, 1304C.

35 Cf. e.g. Emperor Justinian, Contra Monophysitas, 180, ed. E. Schwartz, Drei dogmatische Schriften Iustinians (Abhandlungen der Bayerischen Akademie der Wissenschaften, Philosophisch-

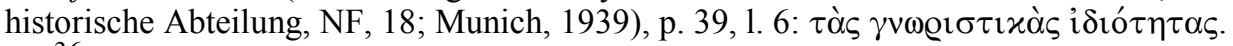

36 This interpretation can be substantiated when we also take into consideration the prepositional

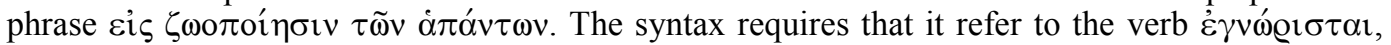
which it precedes. However, the construction is decidedly odd as can be seen from the translation 'is recognised for the purpose of vivifying all things' (this problem is glossed over by Gouillard who translates: 'a été révélé pour la vivification de l'univers'). Indeed, when Greek authors use this verb they invariably construe it with a dative or with a prepositional phrase. Here I will only give two examples: Gregory of Nazianzus states in his twenty-third Oratio that we conceptualise God as 'one and the same ... nature, which is recognised through eternity and birth and procession'

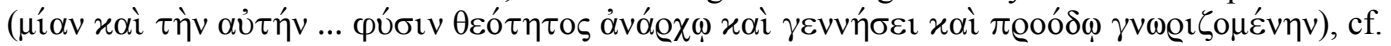
above note 12; and the author of the Pseudo-Cyrillian treatise De sancta trinitate avers that 'the

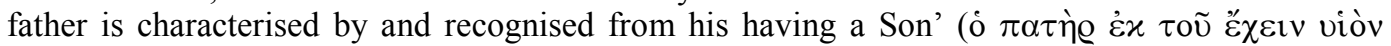
$\chi \alpha \varrho \alpha x \tau \eta \varrho i \zeta \varepsilon \tau \alpha \iota$ x $\alpha \grave{i} \gamma v \omega \varrho i ́ \zeta \varepsilon \tau \alpha \mathrm{l})$, cf. Pseudo-Cyril, De sancta trinitate, $P G$ 77, 1149C. In order to make sense of Methodius' sentence we therefore need to supply such an element to which the

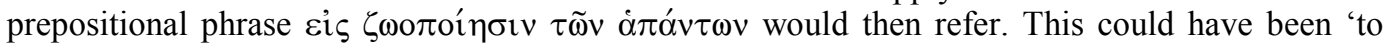
be', but it could equally have been 'to project', which is after all the characteristic property of the

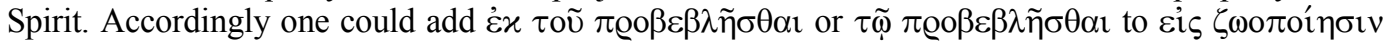

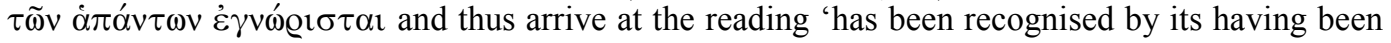
projected for the purpose of vivifying all things', which drives home the point that the verb $\pi$ @o-

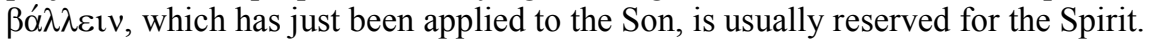

Dirk Krausmüller, 'From Homoousion to Homohypostaton: Patriarch Methodius of Constantinople and Post-Patristic Trinitarian Theology,' in: Journal for Late Antique Religion and Culture 3 (2009) 1-20; ISSN: 1754-517X; Website: http://www.cardiff.ac.uk/clarc/jlarc 


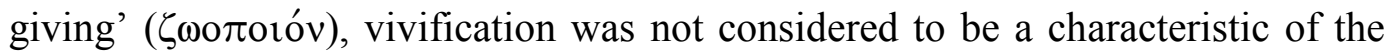
third person of the Trinity alone. The Old Testament contains passages such as II Esdras 19:5: 'You are yourself the only Lord: you have made the heaven and ...

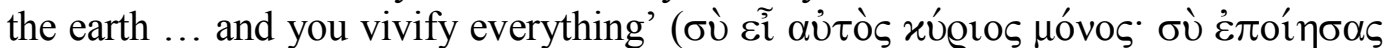

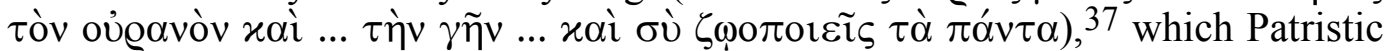
authors interpreted as referring to all three divine persons and therefore to the divine nature. Cyril of Alexandria, for example, asserts in his Commentary on the Gospel of John that 'the creator of all things vivifies ... all things since he is life

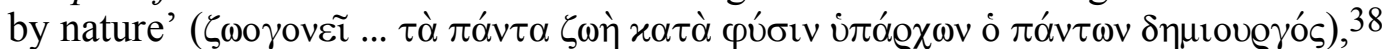
and Anastasius of Antioch speaks even more explicitly of God as 'life and living

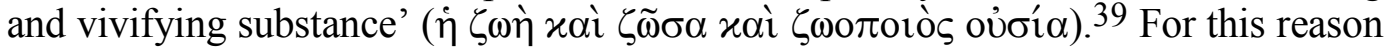
the champions of the full divinity of the Spirit in the late fourth century regularly refer to this operation in their attempts to 'prove' its consubstantiality with the Father and the Son. Accordingly the Spirit can be identified not only as $\sigma u v \delta \eta \mu 1-$ ovgróv but also as $\sigma 0 \zeta \omega 0 \pi 010$ v as it is indeed by Cyril of Alexandria who calls it

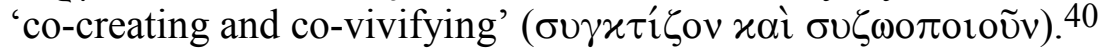

This argument can be taken even further. In those instances in the New Testament where vivification is mentioned in combination with 'spirit' this spirit is identified not with the third but with the second person of the Trinity. This is explicitly stated in I Corinthians 15:45 where the formula 'vivifying spirit' ( $\pi v \varepsilon \widetilde{u} \mu \alpha \zeta \omega 0 \pi$ oróv) refers to the incarnated Son as the 'last Adam' ('ڤ $\sigma \chi \alpha \tau o \varsigma^{\prime}$ 'A $\left.\delta \alpha \mu\right),{ }^{41}$ and is certainly also the most obvious reading of John 6:63 and II Corinthians 3:6 where the spirit is juxtaposed with the flesh or the letter. ${ }^{42}$ The use of this formula in the context thus does not only not introduce a specific operation of the Spirit but also reminds the readers that the name 'spirit' $(\pi v \varepsilon \tilde{u} \mu \alpha)$ itself is not exclusively used to denote the third person of the Trinity since Scripture teaches both that 'God is spirit' ( $\pi v \varepsilon \tilde{v} \mu \alpha$ ó $\theta \varepsilon o ́ \varsigma)$ and that 'the Lord is the spirit' (ó xú@ı One could even argue that Methodius' refusal to insert an explicit reference to the third person of the Trinity is meant to highlight the fact that there is not a single term that can be exclusively attributed to it. Here, too, his approach is diametrically opposed to that of other theologians: Anastasius of Antioch had been forced to concede that all three persons can be called both 'holy' and 'spirit' but had then

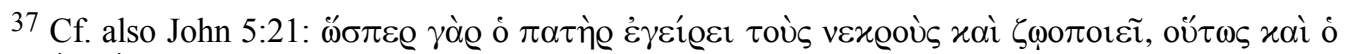

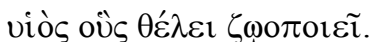

38 Cyril of Alexandria, Commentary on the Gospel of John, ed. P. E. Pusey and T. Randall, Commentary on the Gospel according to S. John, by Cyril, Archbishop of Alexandria, vol. 2 (A library of Fathers of the Holy Catholic Church, 43; Oxford, 1885), p. 445, 11. 10-16.

${ }^{39}$ Cf. e.g. Anastasius of Antioch, Expositio dogmatica, I.1.13, ed. Sakkos, p. 21, 11. 1-2.

40 Cyril of Alexandria, De sancta trinitate dialogi septem, VII, $P G 75,1116 \mathrm{~B}$.

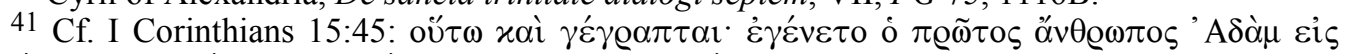

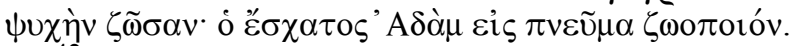

42 John $6: 63$ is a statement about the Son's descent into this world: here spirit clearly denotes the Son's divinity. In the case of II Corinthians 3:6 the connection with the Son is established in verse 17 of the same chapter.

43 John 4:24; II Corinthians 3:17.

Dirk Krausmüller, 'From Homoousion to Homohypostaton: Patriarch Methodius of Constantinople and Post-Patristic Trinitarian Theology,' in: Journal for Late Antique Religion and Culture 3 (2009) 1-20; ISSN: 1754-517X; Website: http://www.cardiff.ac.uk/clarc/jlarc 
insisted that the combination of the two terms is only found in the case of the third person of the Trinity. 44

At this point we can conclude that in the first part of the subordinate clause Methodius has constructed a statement that ambiguates attributes of divine persons and thus erodes the conceptual framework on which traditional Trinitarian theology was based. As we have seen he creates a context where all specific markers of the third person of the Trinity, its name, its operation and its mode of existence, are attributed, either explicitly or through implication, to the second person of the Trinity. ${ }^{45}$

II.

The argument that has been presented so far has been based on the unstated assumption that Methodius' attempts at ambiguation are limited to the Spirit and do not affect the Word or Son. However, is this really the case? Here we need to

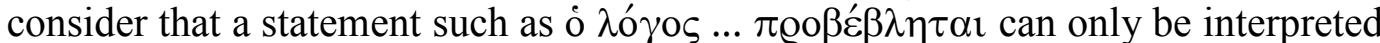
as referring to the second person if we accept that a 'name' is more unequivocal than a characteristic property. However, from the allusion to I Corinthians 15:45 we can conclude that this is not so in the case of the Spirit, and Methodius offers us no reason why we should consider this to be different in the case of the Word or Son. Accordingly we can argue that the term Word could also refer to the third person of the Trinity, which is 'projected' from the Father.

In order to substantiate this hypothesis I will look more closely at the verb $\dot{\omega} \mu \mathrm{o}-$

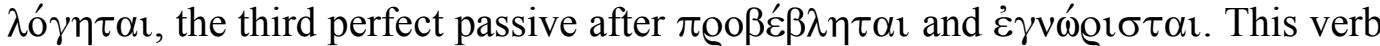
will initially be taken to mean 'is agreed' or 'is confessed' and will conjure up the phrase 'confession of faith' (o $\left.\mu 0 \lambda \sigma \gamma^{\prime} \alpha \tau \tilde{\eta} \varsigma \pi i \sigma \tau \varepsilon \omega \varsigma\right),{ }^{46}$ in particular since the subject appears to be 'one God' ( $\varepsilon \tilde{i} \varsigma \theta \varepsilon o ́ s)$. However, here one needs to consider that it occurs in a context which is saturated with composita containing the element

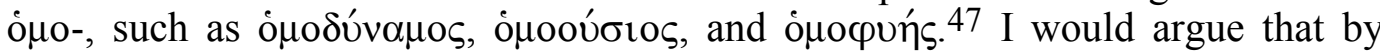
creating this cluster Methodius signals to his readers that o $\mu \circ \lambda \circ \gamma \varepsilon \tilde{i} v$ is morphologically similar to such words and that he thus alerts them to the existence of the

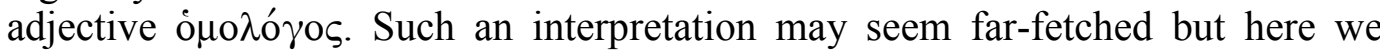
need to take into account a dimension of Methodius' texts that I have already mentioned at the beginning of this article, namely that words are not used in their

\footnotetext{
44 Anastasius, Expositio dogmatica, I.1.60-61, ed. Sakkos, p. 35, 11. 19-29.

45 Such a reading is further insinuated to the reader by the fact that it would make much better

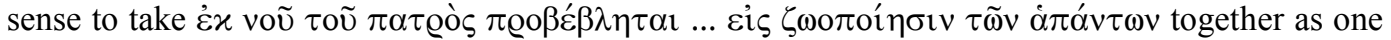
statement. Of course, such a reading is ruled out by the presence of the copula $x \alpha$ í but readers cannot help but notice that it would be much more 'natural' than the one required by the syntax. This is not the only case of such an oddity in the text, cf. Gouillard, 'Vie d'Euthyme', p. 69, note 134.

46 Cf. e.g. Methodius, Life of Euthymius, 9, ed. Gouillard, p. 35, 1. 179.

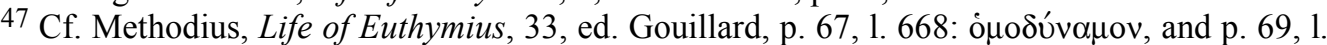

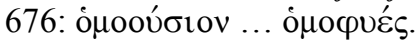

Dirk Krausmüller, 'From Homoousion to Homohypostaton: Patriarch Methodius of Constantinople and Post-Patristic Trinitarian Theology,' in: Journal for Late Antique Religion and Culture 3 (2009) 1-20; ISSN: 1754-517X; Website: http://www.cardiff.ac.uk/clarc/jlarc
} 
conventional sense but given meanings that are suggested by the components of which they are made up. 48

For the sake of brevity I will mention only one example here, which comes from a passage in Methodius' Encomium of Agatha, where the posthumous activity of the saint is described. There Methodius tells his audience that the martyr has reddened her face and her dress with the blood of the lamb 'in order to flood the

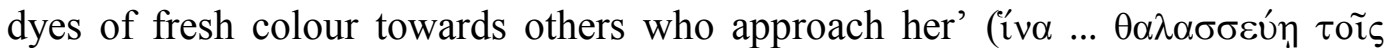

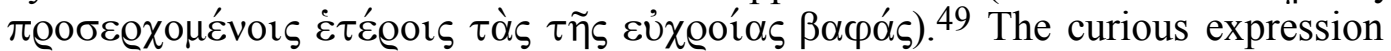

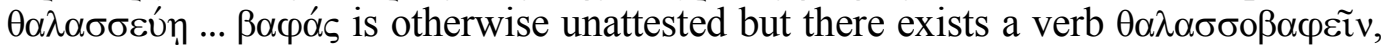
which means 'to dye purple'. 50 There can be no doubt that Methodius derived $\theta \alpha \lambda \alpha \sigma \sigma \varepsilon u ́ n . . . \beta \alpha \varphi \alpha ́ s$ from this verb because in the same context he uses the synonymous $\alpha \lambda \imath \beta \alpha \varphi^{\prime} \alpha$ in its conventional sense, 'dyeing purple', and the unequivocal term $\pi$ og̣úg $\omega \sigma 1 \varsigma^{51}$ Here we thus have a case where Methodius deconstructs a term and uses its constituent parts in their literal meaning. This gives an idea of the complexity of his texts and goes at least some way to showing that a

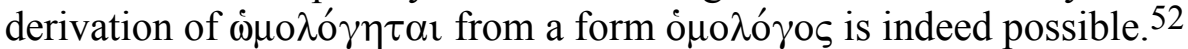

What would be the purpose of such manipulation in the excursus in the Life of Euthymius? Even if $\dot{\omega} \mu \mathrm{o} \lambda \mathrm{o}_{\gamma} \eta \tau \mathrm{\imath}$ is formally similar to other compounds with o $\mu \mathrm{o}-$ there is, of course, a crucial difference: the other terms refer to the common divinity, which confers on each of the three divine persons not only the same ov' $\sigma$ í $\alpha$ and

48 This finds its explanation in the great importance of lexicography and etymology for the theological discourse of the seventh to ninth centuries. The author of an anonymous sermon on the Annunciation, for example, employs arguments based on etymology and frequently borrows technical terms from the etymological discourse, cf. e.g. Pseudo-Athanasius, Sermon on the Annuncation, 3 ,

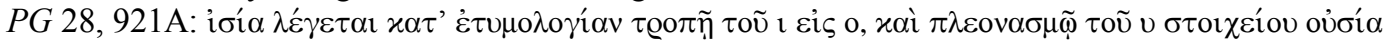
$\delta 1 \varepsilon \varrho \mu \eta v \varepsilon u ́ \varepsilon \tau \alpha 1$. It is suggestive that one etymological lexicon of the ninth century is attributed to an author named Methodius, cf. R. Reitzenstein, ' $\mathrm{Zu}$ den Quellen des sogenannten Etymologicum magnum. 2) Das etymologische Werk des Methodios', Philologos 49 (1890), pp. 400-420.

${ }^{49}$ Methodius, Encomium of Agatha, 3, ed. Mioni, p. 78, 11. 10-11.

50 Cf. e.g. Philo of Byzantium, 2, ed. K. Brodersen, Reiseführer zu den Sieben Weltwundern.

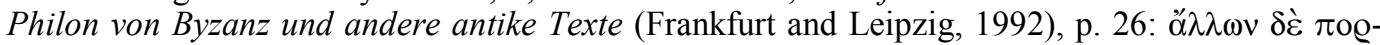

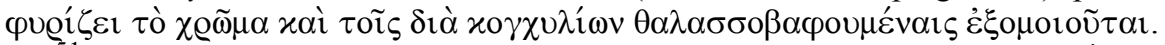

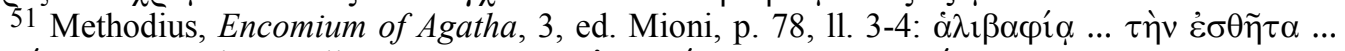

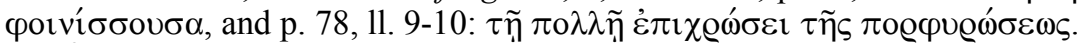

52 Indeed the same passage contains an even closer parallel to the excursus in the Life of Eu-

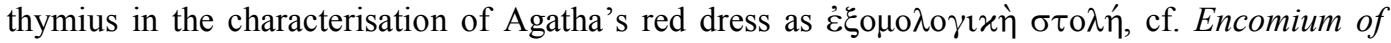
Agatha, 3, ed. Mioni, p. 78, 1. 10. This phrase, which is evidently inspired by Biblical phrases such

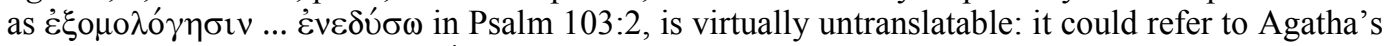

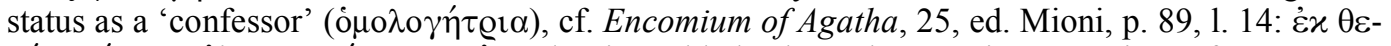

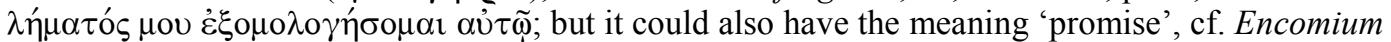

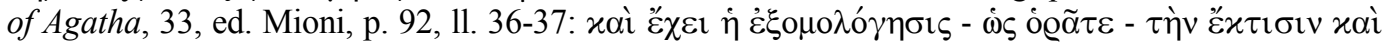

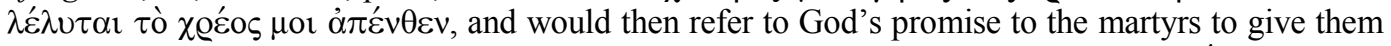
a full reward in Revelation $6: 11$, which is there accompanied by the gift of a $\sigma \tau 0 \lambda \eta \dot{n}$. Moreover, Methodius does not use the regular adjective $\dot{\varepsilon} \xi o \mu о \lambda o \gamma \eta \tau \iota x \eta ́$ but instead employs the otherwise

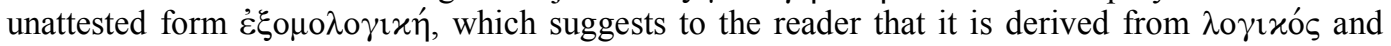
which thus introduces a third theme, namely that in the case of Agatha the colour of the dress takes the place of 'words' (@ं $\mu \alpha \tau \alpha)$ as a means of communciation with the faithful, cf. Encomium of

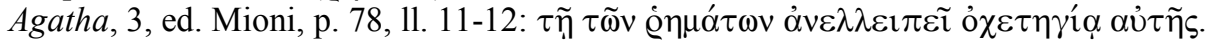

Dirk Krausmüller, 'From Homoousion to Homohypostaton: Patriarch Methodius of Constantinople and Post-Patristic Trinitarian Theology,' in: Journal for Late Antique Religion and Culture 3 (2009) 1-20; ISSN: 1754-517X; Website: http://www.cardiff.ac.uk/clarc/jlarc 


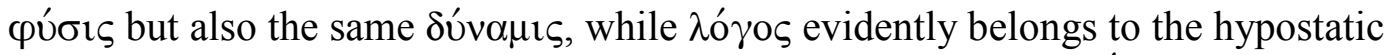
sphere. A claim, however, that the third person of the Trinity is $\lambda$ ó $\gamma_{0} \varsigma$ in the same way as the second person is $\lambda$ ó $\gamma$ os can only lead to further erosion of the accepted Trinitarian framework. 53

In order to substantiate this hypothesis we need to return one more time to the terms that Methodius uses in the excursus in order to express consubstantiality: there

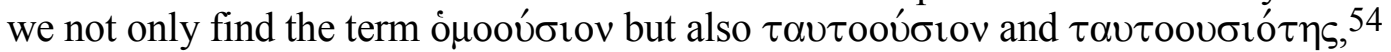
which suggests not only that the two terms are interchangeable but also that the two elements o $\mu o-$ and $\tau \alpha u \tau o-$ are equivalent. That this is indeed the case can be seen from a passage in Methodius' Life of Theophanes:

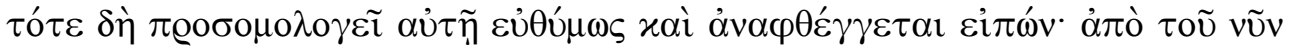

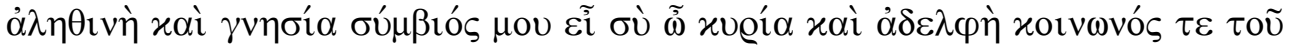

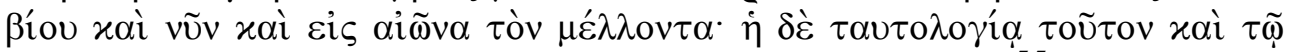

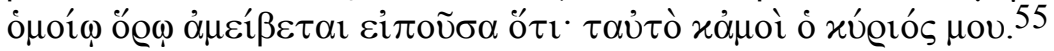

Then he confessed to her fervently and spoke up: 'From now on you are my true and genuine spouse, my lady and sister, and my companion for life both now and in the life to come.' And she responded to him with the same words and with a similar definition: 'The same is true for me as well, my lord.'

In this passage the young saint outlines his vision for a chaste marriage and his bride signals her agreement. The unanimity of the couple is reinforced on the formal level in the clauses that introduce the two statements: they both contain twenty-

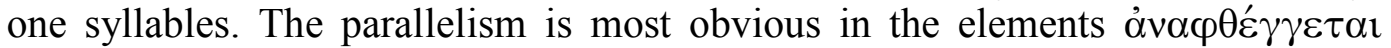

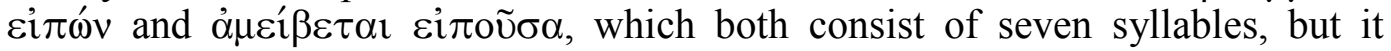
extends also to the first parts of the two clauses: the two correlated expressions $\tau \alpha \nu \tau o \lambda o \gamma^{\prime} \underline{\alpha} \alpha$ and $\tau \tilde{\omega}$ o $\mu$ oí $\omega$ ó $\omega$ each take up a part of the preceding verb $\pi \varrho o \sigma-$

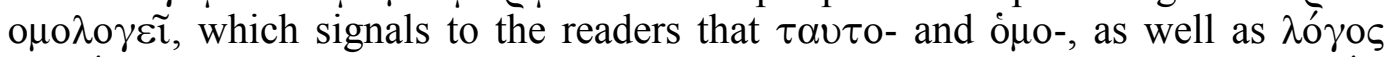
and ögos, are synonymous, and thus suggests an equivalence between ó $\mu \mathrm{o} \lambda \mathrm{o} \gamma \dot{i} \alpha$ and $\tau \alpha \nu \tau o \lambda o \gamma^{\prime} \alpha$. This is a clear example of how Methodius provides his readers with clues that help them make sense of his writings. I would therefore argue that in the Life of Euthymius, too, the readers are meant to consider $\dot{\omega} \mu \mathrm{o} \lambda \mathrm{o} \gamma \eta \tau \alpha \mathrm{l}$ as equivalent to $\tau \alpha \nu \tau o \lambda o ́ \gamma \eta \tau \alpha$. Late Antique rhetorical treatises define $\tau \alpha \nu \tau o \lambda o \gamma^{\prime} \alpha$

53 I would argue that Methodius has even construed an immediate context that would make his readers aware of such a possibility: in the first half of the sentence the vió $\varsigma$ was referred to as $\lambda$ ó $_{0} \zeta$,

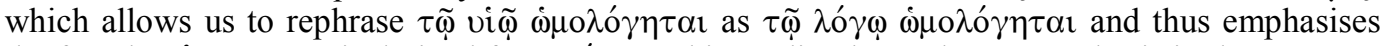

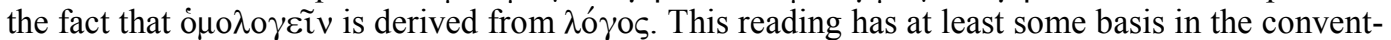
ional use of the verb ó ${ }_{0} \lambda \sigma \gamma \varepsilon \tilde{\imath} v$, which does not only have the meaning 'to confess' but can also be used in the sense of 'correspond' or 'conform', cf. Liddell \& Scott, A Greek-English Lexicon

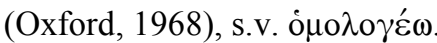

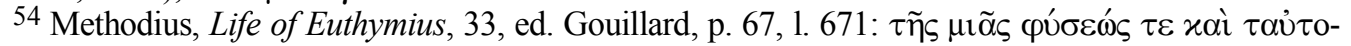

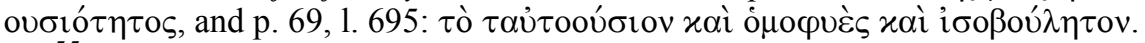

55 Life of Theophanes, 13, ed. V. V. Latyšev: Methodii Patriarchae Constantinopolitani Vita S. Theophanis Confessoris (Zapiski rossijkoj akademii nauk. viii. ser. po istoriko-filologičeskomu otdeleniju, 13.4; Petrograd, 1918), p. 10, 11. 3-7.

Dirk Krausmüller, 'From Homoousion to Homohypostaton: Patriarch Methodius of Constantinople and Post-Patristic Trinitarian Theology,' in: Journal for Late Antique Religion and Culture 3 (2009) 1-20; ISSN: 1754-517X; Website: http://www.cardiff.ac.uk/clarc/jlarc 
as 'a setting side by side of words that mean the same thing, as when we say "they

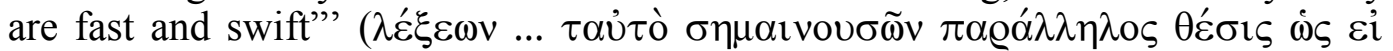

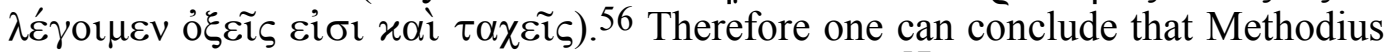
regards the terms $\lambda \operatorname{ó}^{\prime} \mathrm{o} \varsigma$ and $\pi v \varepsilon \tilde{u} \mu \alpha$ as synonymous. ${ }^{57}$

At this point we can sum up the results of the discussion so far: Methodius has eroded all markers of the individuality of the third person of the Trinity and he may well have done the same as regards the second person. This means that there are still two persons, but they can both be called and characterised in the same way. It is evident that this deconstruction of traditional Trinitarian theology also removes the basis for the notion of an Imago Trinitatis in the human being, since there are no longer functionally distinguishable entities at the level of the divinity for which the human mind, speech and breath could serve as an analogy. 58

This raises the question: why would Methodius have embarked on such an extraordinary course? In order to find an answer I will now extend the discussion to the context in which he develops his Trinitarian speculation. This context is a defence of religious imagery against the Iconoclasts. In his argument Methodius starts with a belief that both Iconophiles and Iconoclasts have in common, namely that the written and spoken word is an acceptable vehicle for transporting Christian belief, and then tries to show that word and image are equivalent so that acceptance of one necessarily entails acceptance of the other. This argument is summed up in the following statement:

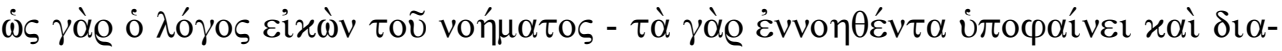

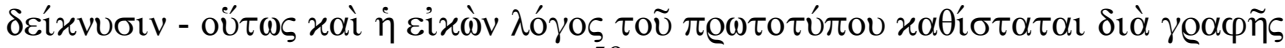

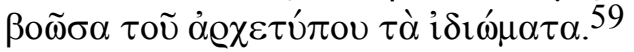

As the word is the image of the thought - for it reveals and shows what has been thought - thus the image is also the word of the prototype, proclaiming the idioms of the archetype.

56 Cf. Phoebammo, De figuris, 1.3, ed C. Walz, Rhetores Graeci, vol. 8 (Stuttgart, 1835), pp. 487-519.

57 In the discussion so far I have considered the meanings of the verb $\dot{\omega} \mu \mathrm{o} \lambda$ ó $\gamma \eta \tau \alpha \mathrm{r}$ and its possible variant $\tau \alpha u \tau o \lambda o ́ \gamma \eta \tau \alpha l$ in isolation. However, we must also ask whether such an inter-

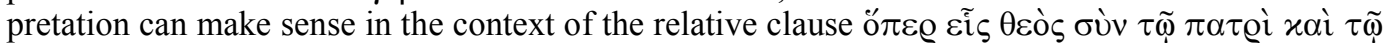
vi $\tilde{\omega} \dot{\omega} \mu \nu \hat{o}^{\gamma} \gamma \eta \tau \alpha \mathrm{l}$ of which it is a part. At first sight the syntax seems to be straightforward: the ele-

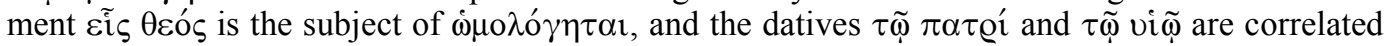
through $x \alpha$ í and therefore both dependent on the preceding preposition oúv. However, this is not the only possible reading because one could see two different statements here, namely ö $\pi \varepsilon Q$ عi $\zeta$

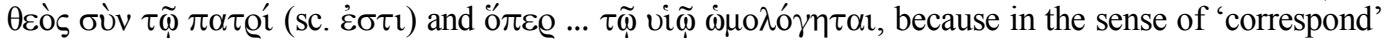
the verb o $\mu 0 \lambda \mathrm{o} \gamma \varepsilon \tilde{\mathrm{i}} v$ is construed with the simple dative. Of course, it is impossible to prove beyond doubt that this interpretation is correct but given Methodius' subtle manipulations in the first part of the subordinate clause we should be reluctant to stop in this case at the superficial level of meaning.

58 This may, however, not be as much of a contradiction as it first seems: here we need to remember that Methodius had always presented his distinction in terms of operations ad extra.

${ }^{59}$ Methodius, Life of Euthymius, 32, ed. Gouillard, p. 67, 11. 658-660.

Dirk Krausmüller, 'From Homoousion to Homohypostaton: Patriarch Methodius of Constantinople and Post-Patristic Trinitarian Theology,' in: Journal for Late Antique Religion and Culture 3 (2009) 1-20; ISSN: 1754-517X; Website: http://www.cardiff.ac.uk/clarc/jlarc 
The exegesis of Genesis 1:26, which we have been discussing so far, is then introduced as Biblical corroboration of this claim. As we have seen in our analysis

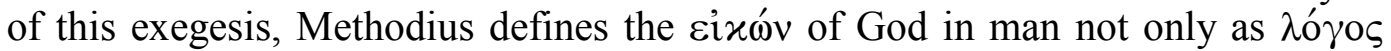

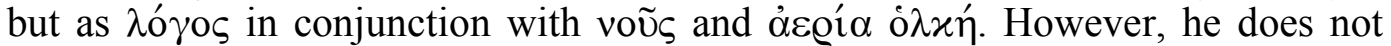
lose sight of the point that he is trying to prove as can be seen from the following statement that he makes in the course of his exegesis:

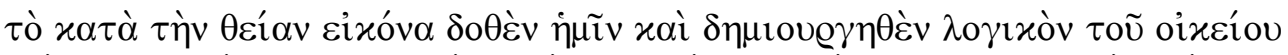

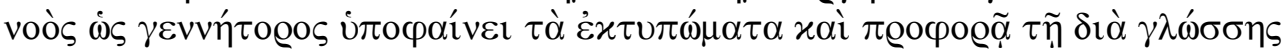

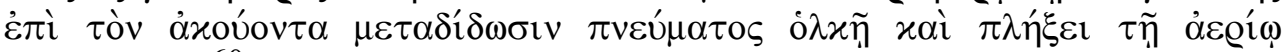
$\tau \cup \pi \mathrm{T} \mu \varepsilon^{\prime}$ vov. 60

The 'wordliness', that has been created and has been given to us according to the divine image shows the impressions of the mind as begetter and through utterance by tongue passes on to the listener the spirit that is being formed through the drawing and beating of air.

Therefore it is not surprising that Methodius concludes his Trinitarian speculations with a restatement of the original hypothesis:

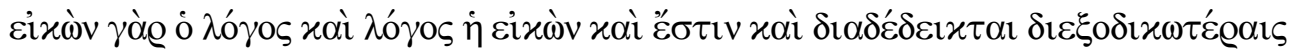

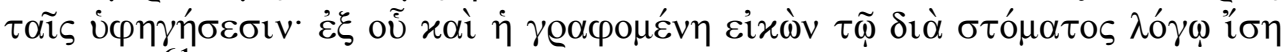

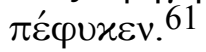

The word is image and the image is word and has been shown to be such through rather effusive explanations for which reason the painted image, too, is equal in nature to the word that comes out of the mouth.

These passages show that Methodius makes his statements about the Trinity in order to support an argument in favour of religious imagery. However, the link between the two themes is not limited to this level; it also extends to the manner in which Methodius presents his argument and therefore can help to elucidate the reasons that caused him to ambiguate the inner-Trinitarian relations.

In order to see how this is possible we need to have a closer look at the introductory passage to the excursus about the divine image, which I have just quoted. There Methodius highlights the functional similarity between word and image both make manifest things that would otherwise remain hidden - but he does not make his point by introducing a third more general category such as for example 'sign'. Instead he takes the functional similarity as the starting point for attribution

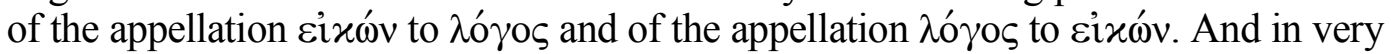
much the same way he also does not appeal to the common trait of 'communication'

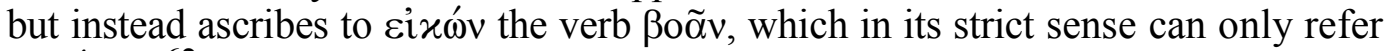
to $\lambda$ ó os. $^{62}$

\footnotetext{
${ }^{60}$ Methodius, Life of Euthymius, 33, ed. Gouillard, p. 71, 11. 717-721.

61 Methodius, Life of Euthymius, 35, ed. Gouillard, p. 73, 11. 741-742.

62 In a similar way Methodius identifies the dye of Agatha's dress with her speech, see above note 52 .

Dirk Krausmüller, 'From Homoousion to Homohypostaton: Patriarch Methodius of Constantinople and Post-Patristic Trinitarian Theology,' in: Journal for Late Antique Religion and Culture 3 (2009) 1-20; ISSN: 1754-517X; Website: http://www.cardiff.ac.uk/clarc/jlarc
} 
It is evident that this approach is very similar to the way in which Methodius treats $\lambda$ ó $\sigma_{0} \varsigma$ and $\pi v \varepsilon \tilde{v} \mu \alpha$ in his statement about the Trinity. There, too, he starts from a functional similarity, the origin in the Father, and then applies to the $\lambda$ ó $\gamma \circ \varsigma$ the verb $\pi \varrho \circ \beta \alpha \dot{\alpha} \lambda \lambda \varepsilon \sigma \theta \alpha$, which in traditional Trinitarian terminology refers to the Spirit, and as I have tried to argue he also insinuates that the Spirit can be referred

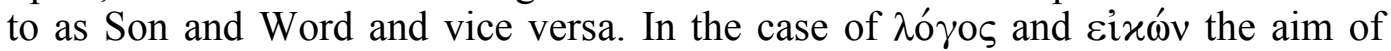
Methodius' manipulations is to show that the two phenomena are equivalent. Therefore one can argue that his Trinitarian speculations have a similar purpose, namely to safeguard the unity of the Trinity. Here, too, Methodius does not establish a link between the divine persons through introduction of the divine substance as a more general category, but instead seeks to establish it through mutual attribution of 'hypostatic' characteristics to the two persons that originate in the Father.

At this point one could object that Methodius repeatedly speaks of the consubstantiality of the Trinity. However, this does not permit us to assume that he employs the concept in its traditional sense. In the concluding passage of the excursus Me-

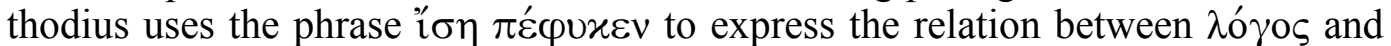

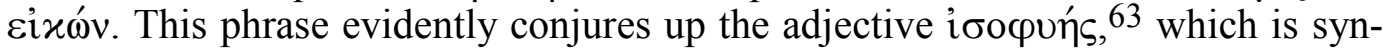
onymous with the term ópopuns that Methodius uses in the Trinitarian excursus to denote the consubstantiality of the three divine persons. This means that the two phenomena are considered to be 'consubstantial' but not by virtue of having a common substrate: the consubstantiality is rather sought in analogies at the phenomenological level. There can be no doubt that Methodius wished his readers to apply this understanding of consubstantiality to the Trinity as well because the

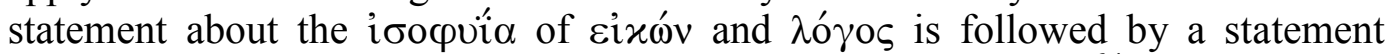
about the Son as عixív, which contains the same verb $\pi \dot{\varepsilon} \varphi v x \varepsilon v .{ }^{64}$

III.

Methodius' speculations are so far removed from the Patristic consensus that one might consider them to be utterly idiosyncratic. However, it can be shown that they are part of a wider debate. In order to make my case I will first look at three texts from the eighth and ninth centuries, a Sermon on the icon of Mary 'the Roman', Epiphanius of Kallistratos' Life of Mary, and the Letter of the three Patriarchs to Emperor Theophilus, which contain descriptions of the appearance of Christ. In each case Christ's features are compared with those of his mother Mary: the anonymous author of the Sermon states at the end of a list of common features that

63 Methodius uses the adjective íọvís elsewhere in the text, cf. Life of Euthymius, 20, ed.

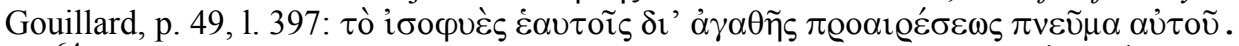

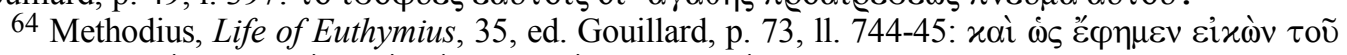

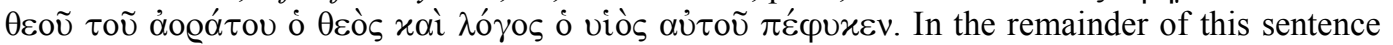
the Father and the Spirit are again added to the Son to take account of the imago Trinitatis.

Dirk Krausmüller, 'From Homoousion to Homohypostaton: Patriarch Methodius of Constantinople and Post-Patristic Trinitarian Theology,' in: Journal for Late Antique Religion and Culture 3 (2009) 1-20; ISSN: 1754-517X; Website: http://www.cardiff.ac.uk/clarc/jlarc 
Christ was 'simply like the appearance of his mother' ( $\dot{\alpha} \pi \lambda \tilde{\omega} \varsigma \dot{\omega} \varsigma \dot{0} \tau \tilde{\eta} \varsigma \tau \varepsilon x o u ́ \sigma \eta \varsigma$ $\chi \alpha \varrho \alpha x \tau \eta \dot{\eta} \mathrm{Q}),{ }^{65}$ Epiphanius concludes with the statement 'for in all respects he shared

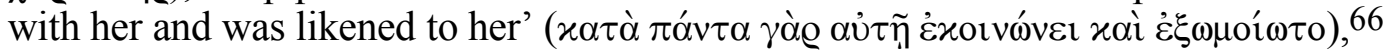
and in the Letter of the three Patriarchs we find the similar formula 'showing the

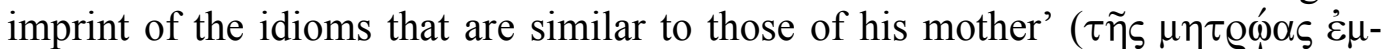

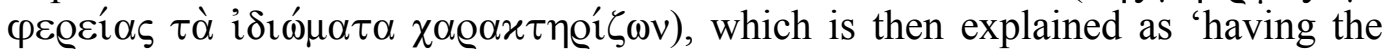
colour of wheat in his appearance according to the appearance of the mother'

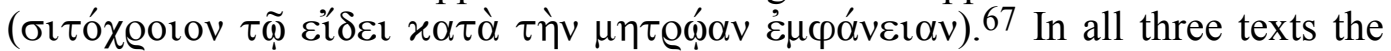
similarity is thus clearly seen in 'hypostatic' terms and Christ is presented as being 'in the image' of Mary. This impression is reinforced by another comparison: Christ is described as having 'cheerful eyes' (o’ $\varphi \theta \alpha \lambda \mu$ où $\left.\chi \alpha \varrho \circ \pi \circ{ }^{\prime} \varsigma\right)$, which is how the Bible characterises David, Christ's human ancestor. ${ }^{68}$ What is conspicuously absent from these statements is the concept of a consubstantiality 'with us', that is, humankind, of which Mary, David and Christ's human dimension are individual realisations.

At this point it could be objected that the Letter of the Three Patriarchs at least contains a further passage where this shift has not taken place: there we are not only told that Christ 'expressed the idioms of the likeness to Mary' but also that

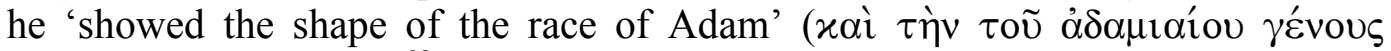
$\mu o ́ \varrho \varphi \omega \sigma i v ~ \varepsilon \dot{\mu} \varphi \alpha i ́ v \omega v){ }^{69}$ At first sight this seems to refer to human nature as such: John of Damascus, for example, says in his Sermon on Holy Saturday that

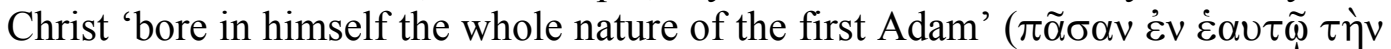

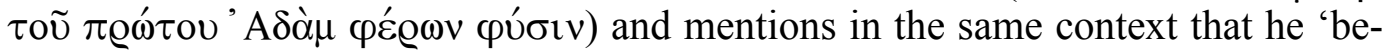

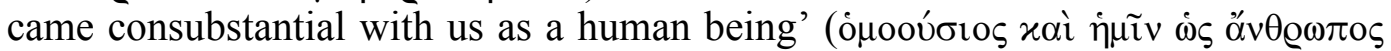

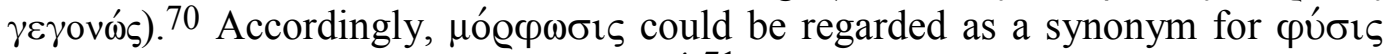
as was indeed often the case with $\mu$ o@ $\varphi \eta^{71}$ Yet when we look more closely at the context this interpretation is called into question. As we have seen the parallel statement about Christ's resemblance to his mother is phrased in a very similar

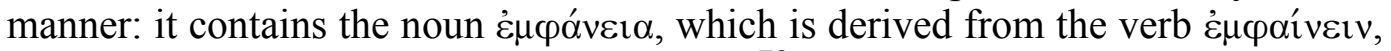

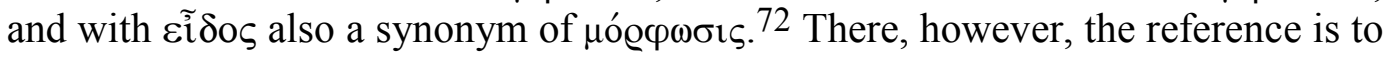

65 Sermon on the Image of Maria Rhomaia, ed. E. v. Dobschütz, Christusbilder. Untersuchungen zur christlichen Legende, 3: Beilagen (TU, 18.3, NS, 3; Leipzig, 1899), p. 247**.5.

${ }^{66}$ Epiphanius of Kallistratos, Life of the Godbearer, ed. Dobschütz, Christusbilder, vol. III, p. $302 * *$, 11. 20-21.

${ }^{67}$ Letter of the Three Patriarchs, ed. Dobschüt, Christusbilder, vol. III, p. 303**, 1. 11.

68 Epiphanius, Life of the Godbearer, ed. Dobschütz, Christusbilder, vol. III, p. 302**, 1. 8-10; cf. I Kings 17:42.

${ }^{69}$ Letter of the Three Patriarchs, ed. Dobschüt, Christusbilder, III, p. 303**.4-5.

70 John of Damascus, Sermo in Sabbatum sanctum, 12, ed. B. Kotter, Die Schriften des Johannes von Damaskos, vol. V: Opera homiletica et hagiographica (PTS, 29; Berlin and New York,

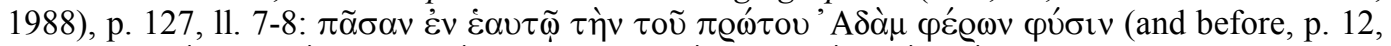

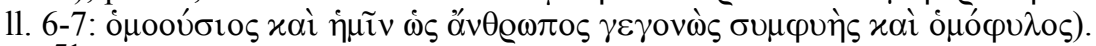

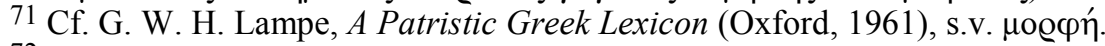

72 Cf. also the whole sentence in the Letter of the Three Patriarchs, ed. Dobschütz, Christusbilder,

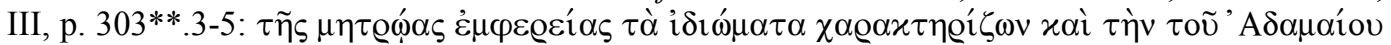

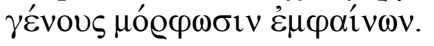

Dirk Krausmüller, 'From Homoousion to Homohypostaton: Patriarch Methodius of Constantinople and Post-Patristic Trinitarian Theology,' in: Journal for Late Antique Religion and Culture 3 (2009) 1-20; ISSN: 1754-517X; Website: http://www.cardiff.ac.uk/clarc/jlarc 
a specific hair colour and thus to a 'hypostatic' characteristic and not to the common properties of man as a species. This suggests that in the case of Adam, too, the author of the Letter of the Three Patriarchs locates the similarity on the level of individual appearance. Indeed, a similar 'hypostatic' understanding of Christ's relation to Adam can be found in the Questions and Answers of Anastasius of Sinai and of Pseudo-Athanasius, which date to the seventh and eighth centuries. When Anastasius responds to the question whether the resurrected will recognise each other he says that this is not possible because all men will look like Adam before the fall. ${ }^{73}$ To support this view he adds a reference to the Fathers who defined resurrection as 'the restitution to the primeval state of the first man' ( $\tau$ ฑे

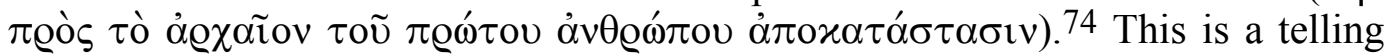
misunderstanding, for the Fathers to whom Anastasius refers had, of course, not conceived of this restitution in terms of outward appearance. ${ }^{75}$ The shift is even more obvious in the treatment of the same question by Pseudo-Athanasius. This author also denies the possibility of mutual recognition after the resurrection and

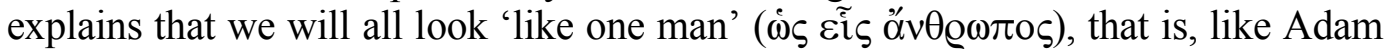
from whom we are all descended: 'each image of a man is like to the image and

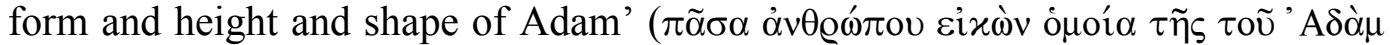

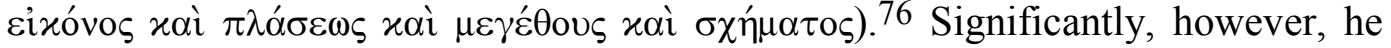
creates a further link between the appearance of the resurrection body and the appearance of Christ, which shows that we are in the presence of the same conceptual framework as is set out in the Letter of the Three Patriarchs. ${ }^{77}$

We can thus conclude that these texts reflect a coherent framework according to which the individual appearances of Christ, of Mary, and of Adam play an important rôle in defining the relation between Christ's human part and other human beings and also in conceptualising a common humanity. This raises the question: why did Methodius and some of his contemporaries no longer seek unity at the level of substance but rather at the level of hypostatic idioms or, in Patristic terms,

73 Anastasius of Sinai, Quaestiones, 19.11, ed. M. Richard and J. Munitiz, Anastasii Sinaitae Quaestiones et Responsiones (CC. SG, 59; Turnhout, 2006), p. 34, 1. 95 - p. 35, 1. 102: õ̃os $\gamma \dot{\varepsilon}-$

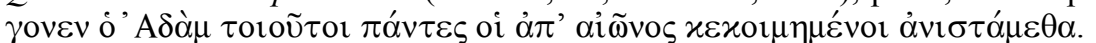

74 Anastasius of Sinai, Quaestiones, 19.11, ed. Richard and Munitiz, p. 35, 11. 102-104.

75 Cf. e.g. Cyril of Alexandria, De recta fide ad Theodosium imperatorem, 36, PG 76, 1188B:

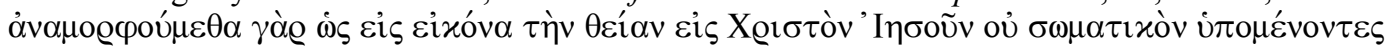

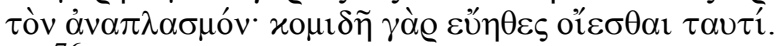

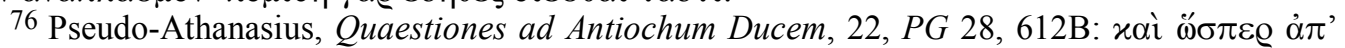

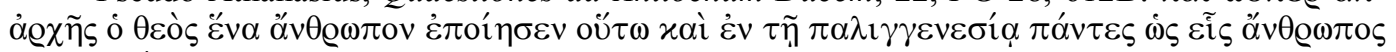
$\dot{\varepsilon} \pi \alpha \nu \imath \sigma \tau \alpha \dot{\mu} \mu \varepsilon \theta \alpha$.

77 Pseudo-Athanasius affirms that all men will be resurrected as 'a thirty year old perfect man ... just as Christ was baptized in his thirtieth year, cf. Pseudo-Athanasius, Quaestiones, 22, PG 28,

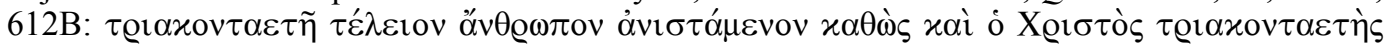
$\dot{\varepsilon} \beta \alpha \pi \tau i \sigma \theta \eta$. This statement is obviously based on Ephesians 4:13 and Luke 3:32. Similar passages are found in later hagiographical texts such as the tenth-century Life of Nephon of Rhinocorura, 90, ed. A. V. Rystenko, Materialy z istorii vizantijs 'ko-slov'jans'koi literatury ta novy (Odessa, 1928), p. 98, 11. 23-24.

Dirk Krausmüller, 'From Homoousion to Homohypostaton: Patriarch Methodius of Constantinople and Post-Patristic Trinitarian Theology,' in: Journal for Late Antique Religion and Culture 3 (2009) 1-20; ISSN: 1754-517X; Website: http://www.cardiff.ac.uk/clarc/jlarc 


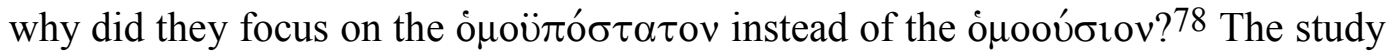
of the post-Patristic discourse is still in its infancy and any attempts at explanation must therefore be provisional. Nevertheless, I would argue that the development, which resulted in Methodius' position, had already begun in the fourth century with the Trinitarian theology of the Cappadocian Fathers. As is well known the Cappadocians countered Eunomius' claim that God's substance is defined by his

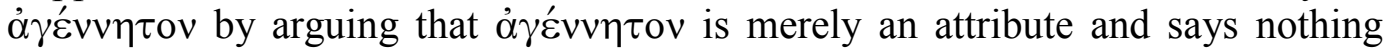
about God's being. In order to support their position they advocated a total disjunction between qualities and substrate. Gregory of Nazianzus, for example, stated that for a satisfactory definition of a substance one needs to know not only qualities but also the substrate 'around which' ( $\pi \varepsilon \mathrm{Q}$ ö $)$ these qualities are found, and then denied that this was possible. ${ }^{79}$ According to the philosophical terminology of the time this reduces all attributes to the status of accidents whereas the core of being becomes completely unknowable. ${ }^{80}$ Such a conceptual framework leaves no room for the traditional Aristotelian view that specific differences are constitutive of substance and are therefore not to be equated with mere accidents. ${ }^{81}$ This disjunction had a decisive influence on later discussions, as can be seen in a famous passage in Leontius of Byzantium's Contra Nestorianos et Eutychianos where ov'oí $\alpha$ is juxtaposed with $\sigma u \mu \beta \varepsilon \beta \eta x$ ó $\varsigma$ and the latter is defined as 'all qualitites, both those, which are called substantial, and those, which are called para-substantial' ( $\pi \tilde{\alpha} \sigma \alpha \iota$

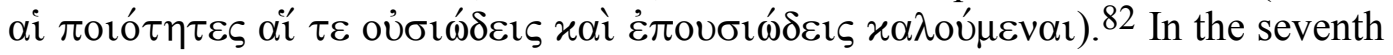
and eighth centuries the assimilation of substantial qualities to accidents was taken even further. In his Ambigua Maximus restates the Cappadocian position that 'the multitude of that which is seen around them is not sufficient for the complete

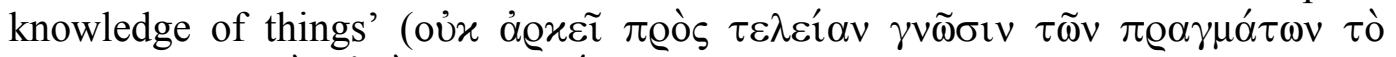

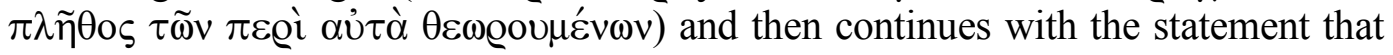
'as regards being-itself no being is that which is and is referred to as the aggregate of the things that we think of or refer to as around it; but that around which those

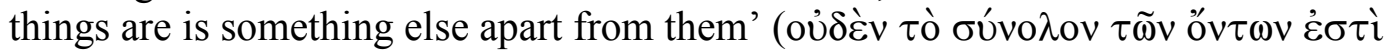

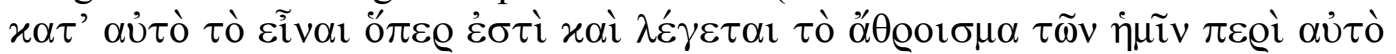

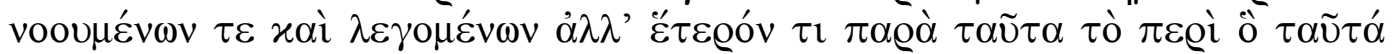
$\dot{\varepsilon} \sigma \tau \imath) .83$

The term $\alpha$ ' $\theta \mathrm{gov} \sigma \mu \alpha$, which is used here, denotes an unstructured 'heap' and had traditionally been reserved for hypostatic idioms. Porphyry, for example, states in

\footnotetext{
78 For a juxtaposition of the two terms in a statement about Christ's relation to the Father and to David, cf. Leontius of Jerusalem, Contra Nestorianos, II.1, PG 86, 1533B.

${ }^{79}$ Gregory of Nazianzus, Orationes, XXVIII.9, ed. Gallay, p. 118, 1. 15.

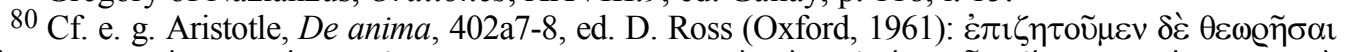

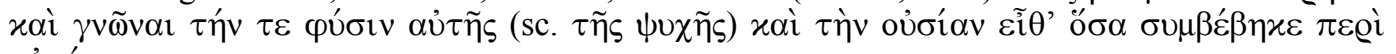

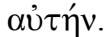

${ }^{81}$ Cf. e.g. M. V. Wedin, Aristotle's theory of substance: the Categories and Metaphysics Zeta (Oxford and New York, 2002).

82 Leontius of Byzantium, Contra Nestorianos et Eutychianos, PG 86, $1277 \mathrm{D}$.

83 Maximus, Ambigua, $P G$ 91, $1225 \mathrm{CD}$.
}

Dirk Krausmüller, 'From Homoousion to Homohypostaton: Patriarch Methodius of Constantinople and Post-Patristic Trinitarian Theology,' in: Journal for Late Antique Religion and Culture 3 (2009) 1-20; ISSN: 1754-517X; Website: http://www.cardiff.ac.uk/clarc/jlarc 
his Isagoge that 'such things are called individuals because each of them is made up of idioms whose aggregate could not ever come into being in another one identically'

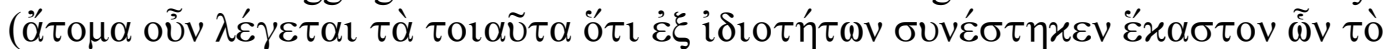

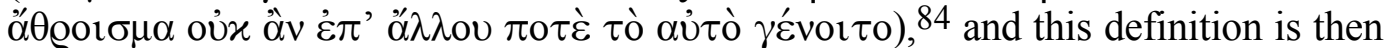
reproduced in Patristic texts where hypostasis is characterised as an 'aggregate of

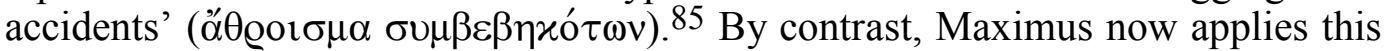
term to the properties of species. This shift is even more obvious in the writings of John of Damascus. In his treatise De duabus in Christo voluntatibus John states that it is impossible for a nature to exist without its natural idioms, which constitute it and which distinguish it from the other natures, and then adds the comment 'the

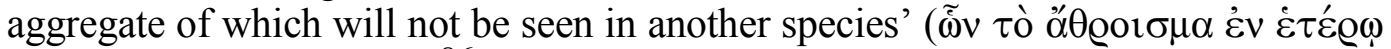

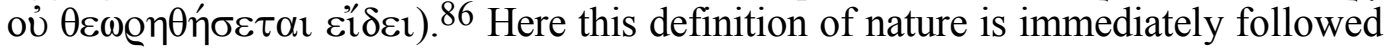
by the traditional definition of hypostasis as being constituted and distinguished from other hypostases through hypostatic idioms 'the aggregate of which cannot

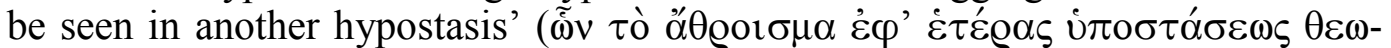

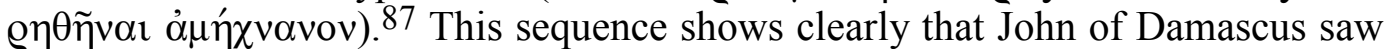
no categorical difference whatsoever between substantial and hypostatic qualities: both are unstructured assemblages. Under these circumstances it comes as no surprise that some late Patristic authors no longer define oúoí $\alpha$ in Aristotelian fashion as a combination of genus and specific differences but rather give long descriptive lists. For example, in a Pseudo-Athanasian Sermon on the Annunciation, which can be dated to the eighth or to the early ninth century, the human ovo' $\alpha$ is defined as the ${ }_{\alpha} \theta \varrho o t \sigma \mu \alpha$ of the following idioms: 'created, ... intelligent, rational, animate, corporeal, passible, soluble, subject to time, mortal, capable of being born, corruptible, capable of growth, changeable, alterable, capable of feeling sorrow, and whatever else can be said equally about a human being by way of selection and analogy' ( $\tau$ ò

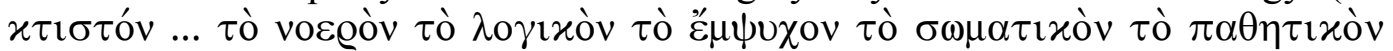

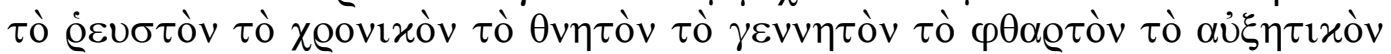

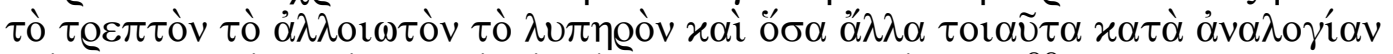

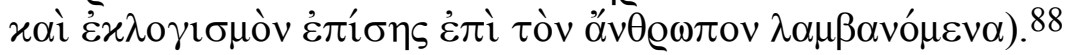

Unlike the Cappadocians, the author of the Sermon on the Annunciation use the

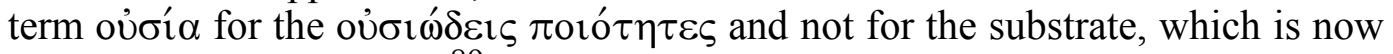
identified with hypostasis. ${ }^{89}$ However, this shift in the meaning of nature and hy-

${ }^{84}$ Porphyry, Isagoge, ed. A. Busse, Porphyrii Isagoge et in Aristotelis Categorias commentarium

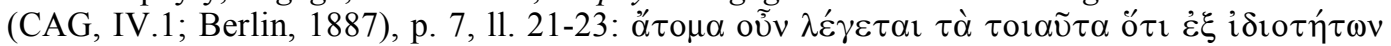

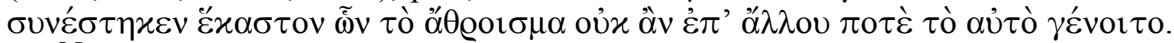

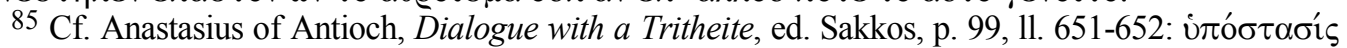

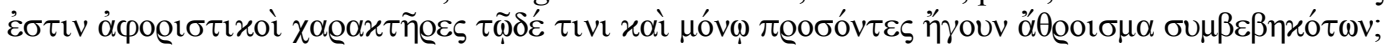

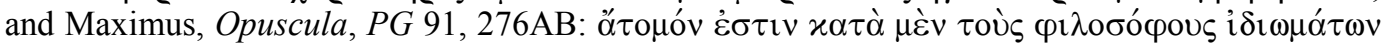

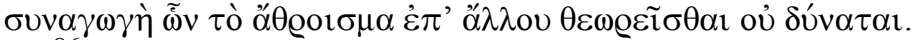

86 John of Damascus, De duabus in Christo voluntatibus, 1, ed. Kotter, p. 173, 11. 1-4.

87 John of Damascus, De duabus in Christo voluntatibus, 1, ed. Kotter, pp. 173-174, 11. 6-10.

88 Pseudo-Athanasius, Sermon on the Annunciation, 3, PG 28, 921A9-14. For the date, cf. M. Jugie, 'Deux homélies patristiques pseudépigraphes', EO 39 (1940), pp. 283-289.

89 This conceptual framework can be traced back to the sixth century. Leontius of Byzantium, for example, states in his Epilyseis that 'the appellation 'Christ' does not signify nature but hypostasis

Dirk Krausmüller, 'From Homoousion to Homohypostaton: Patriarch Methodius of Constantinople and Post-Patristic Trinitarian Theology,' in: Journal for Late Antique Religion and Culture 3 (2009) 1-20; ISSN: 1754-517X; Website: http://www.cardiff.ac.uk/clarc/jlarc 
postasis was primarily due to the constraints of the Christological model developed by the defenders of Chalcedon and did not affect the underlying framework, which is remarkably consistent: a core of being that is beyond human understanding is juxtaposed with accidents. In this framework one can still say that some accidents can be found in all members of a species but this fact does not give these accidents a special status nor permit the conclusion that their totality forms a distinct entity: as we have seen they are nothing more than an 'aggregate' of essentially unconnected features. As a consequence, any likeness short of identity must be considered incomplete and unity can only be achieved if it includes the hypostatic dimension as well. I would argue that this is the context for Methodius' Trinitarian speculations and that his strategy of mutually attributing names and definitions to the Son and the Spirit (as well as to image and word) was a well-considered response to the erosion of the concept of substance. Although he makes his case by exploiting existing terminological ambiguities and would therefore undoubtedly have claimed that he was merely explicating what had already been implicit in traditional Trinitarian theology the solution he arrived at was clearly highly original. And yet it would have been very easy to miss this originality: indeed, Jean Gouillard, the editor of the Life of Euthymius, considered the whole passage to be derivative. ${ }^{90}$ With this article I hope to have shown that far from being fossilised the theological discourse of the late and post-Patristic period produced new and exciting ideas. These ideas are developed within a conceptual framework whose roots can be traced back to the fourth and fifth centuries but which would itself have been completely alien to earlier theologians.

around which (sc. the hypostasis) the natures are seen $<$ and $>$ in which (sc. the natures) the person

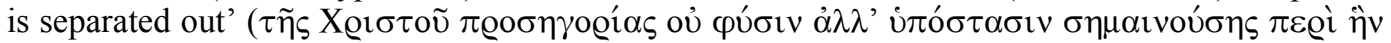

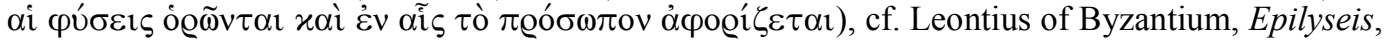
$P G 86,1928$ A.

90 Cf. Gouillard, 'Vie d'Euthyme', p. 16.

Dirk Krausmüller, 'From Homoousion to Homohypostaton: Patriarch Methodius of Constantinople and Post-Patristic Trinitarian Theology,' in: Journal for Late Antique Religion and Culture 3 (2009) 1-20; ISSN: 1754-517X; Website: http://www.cardiff.ac.uk/clarc/jlarc 